ACCEPTED MANUSCRIPT • OPEN ACCESS

\title{
Heart rate variability in patients with cirrhosis: a systematic review and meta-analysis
}

To cite this article before publication: Tope Oyelade et al 2021 Physiol. Meas. in press https://doi.org/10.1088/1361-6579/abf888

\section{Manuscript version: Accepted Manuscript}

Accepted Manuscript is "the version of the article accepted for publication including all changes made as a result of the peer review process, and which may also include the addition to the article by IOP Publishing of a header, an article ID, a cover sheet and/or an 'Accepted

Manuscript' watermark, but excluding any other editing, typesetting or other changes made by IOP Publishing and/or its licensors"

This Accepted Manuscript is @ 2021 Institute of Physics and Engineering in Medicine.

As the Version of Record of this article is going to be / has been published on a gold open access basis under a CC BY 3.0 licence, this Accepted Manuscript is available for reuse under a CC BY 3.0 licence immediately.

Everyone is permitted to use all or part of the original content in this article, provided that they adhere to all the terms of the licence https://creativecommons.org/licences/by/3.0

Although reasonable endeavours have been taken to obtain all necessary permissions from third parties to include their copyrighted content within this article, their full citation and copyright line may not be present in this Accepted Manuscript version. Before using any content from this article, please refer to the Version of Record on IOPscience once published for full citation and copyright details, as permissions may be required. All third party content is fully copyright protected and is not published on a gold open access basis under a CC BY licence, unless that is specifically stated in the figure caption in the Version of Record.

View the article online for updates and enhancements. 


\section{Heart Rate Variability in Patients with Cirrhosis: A Systematic Review and Meta-analysis}

Tope Oyelade $^{1 *}$ (t.oyelade@ucl.ac.uk), Gabriele Canciani² ${ }^{2}$, Gabriele Carbone ${ }^{2}$, Jaber Alqahtani ${ }^{3}$, Kevin Moore ${ }^{1}$, Ali R. Mani ${ }^{1}$.

1. Institute for Liver and Digestive Health, Division of Medicine, University College London, London NW3 2PF, UK.

2. School of Medicine, La Sapienza University, Rome 00185, Italy.

3. Respiratory Medicine, Division of Medicine, University College London, London NW3 2PF, UK.

* Corresponding Author 


\begin{abstract}
:
Background: Cirrhosis is associated with abnormal autonomic function and regulation of cardiac rhythm. Measurement of heart rate variability (HRV) provides an accurate and non-invasive measurement of autonomic function as well as liver disease severity currently calculated using the MELD, UKELD, or ChildPugh scores. This review assesses the methods employed for the measurement of HRV, and evaluates the alteration of HRV indices in cirrhosis, as well as their value in prognosis.
\end{abstract}

Method: We undertook a systematic review using Medline, Embase and Pubmed databases in July 2020. Data were extracted using the Preferred Reporting Items for Systematic Reviews and Meta-Analyses (PRISMA) guidelines. Risk of bias of included studies was assessed by a modified version of the NewcastleOttawa Scale. The studies descriptive were analysed and the standardized mean differences of HRV indices were pooled.

Results: Of the 247 studies generated from our search, 14 studies were included. One of the 14 studies was excluded from meta-analysis because it reported only median of HRV indices. The studies included have a low risk of bias and include 583 patients with cirrhosis and 349 healthy controls. The HRV time and frequency domains were significantly lower in cirrhotic patients. Between-studies heterogeneity was high in most of the pooled studies $(P<0.05)$. Further, HRV indices predict survival independent of the severity of liver disease as assessed by MELD.

Conclusion: HRV is decreased in patients with cirrhosis compared with healthy matched controls. HRV correlated with severity of liver disease and independently predicted survival. There was considerable variation in the methods used for HRV analysis, and this impedes interpretation and clinical applicability. Based on the data analysed, SDNN (standard deviation of inter-beat intervals) and cSDNN (i.e. SDNN corrected for basal heart rate) are the most suitable indices for prognosis in patients with cirrhosis.

Keywords: Chronic Liver Disease, Cirrhosis, Survival, Heart rate variability, Jaundice, Sepsis, Variceal bleeding, MELD, Child-Pugh, UKELD, Biomarker, Hepatology, Acute on chronic liver disease. 


\section{Introduction}

Liver cirrhosis accounts for more than one million deaths annually worldwide, with numbers increasing year on year (1-3). However, patients with cirrhosis have a range of conditions from early uncomplicated cirrhosis which is asymptomatic, to decompensated cirrhosis where organ system start to fail and patients present with many complications such as ascites, hepatic encephalopathy and variceal bleeding $(4,5)$. Once a patient starts to develop complications, various scoring systems including Model for End-Stage Liver Disease (MELD), MELD-Na, or United Kingdom Model for End-Stage Liver Disease (UKELD) are used to calculate prognosis and the need for liver transplant at the bedside or in the clinic. These scoring systems are widely available using Apps on smartphones or web-based calculators. However, the scoring systems do not take into account the alteration in autonomic nervous system (ANS) observed in cirrhosis (6).

A simple and very useful tool to assess the state of the ANS is heart rate variability (HRV). HRV is the variation over time of the intervals between consecutive normal heartbeats (NN). Physiologically, instantaneous heart rate variation represents the capacity to adapt the heart rate (HR) to different internal and environmental circumstances and is modulated by the ANS (7). Tsuji et al. for the first time demonstrated the prognostic value of HRV analysis in the Framingham cohort study and reported that individuals with reduced HRV had increased risk for all-cause mortality (8). HRV provides a non-invasive evaluation of autonomic regulation of the cardiac rhythm and indexes the interplay between the intrinsic cardiac rhythm and external regulatory controls (9). Importantly, with medical advances, it is becoming increasingly recognized that calculation of HRV from a continuous ECG tracing provides additional and clinically useful information to clinicians on both the severity and prognosis of patients with cirrhosis (10).

Although autonomic dysfunction and cirrhotic cardiomyopathy are well established complications of cirrhosis $(11,12)$, these are not assessed by MELD, UKELD or Child-Pugh. This is particularly important since recent reports suggest that HRV predicts survival in cirrhosis independently of MELD and Child-Pugh and therefore may provide additive information currently lacking in existing scoring systems (13-15). However, for HRV to be of value in research and clinical practice, there needs to be standardization of processes that enables simple and accurate assessment of HRV. This includes standardization of the ECG recording techniques, duration of recording, methods, and clinical interpretation of HRV and also the availability of these in the point of care via mobile or web-based apps. The aim of this study was to analyse the methods used to record and report HRV in the literature, assess HRV difference between patients with cirrhosis and controls. 


\section{Method}

This systematic review follows the guideline of the Preferred Reporting in Systematic Reviews and MetaAnalysis (PRISMA) (16). Embase, Medline and Pubmed databases were searched on the $8^{\text {th }}$ of July 2020. An extensive search strategy using Medical Subject Headings (MeSH) terms was performed (Figure S1). Studies retrieved from the search were uploaded to Endnote and duplicates were removed. The duplicate-free studies were then uploaded to Rayyan software and title/abstract screening performed by two independent reviewers.

Furthermore, a mini-systematic review was performed to assess the use of HRV indices as prognostic markers especially in the prediction of survival in patients with cirrhosis. Included papers were simultaneously screened and references searched for studies that performed survival analysis.

\section{Inclusion and exclusion criteria}

Only observational studies were included in the main review. Studies were considered eligible if: either of the HRV time, frequency and non-linear indices were used in assessing autonomic cardiac control in cirrhosis. We excluded studies that did not include control group; studies involving non-cirrhotic liver disease; studies involving pharmacological or non-pharmacological interventions known to affect HRV indices; and studies involving orthostatic tilting as the sole method of HRV assessment. For the mini-systematic review, studies were included if HRV indices of survivals and non-surviving patients were statistically compared irrespective of whether risk analysis was performed.

\section{Data collection}

Titles and abstracts were independently screened for potentially eligible studies and conflict about eligibility resolved through virtual meetings. The eligible articles were then analysed to identify studies meeting the inclusion criteria. All conflicts were resolved by a third reviewer.

Based on predefined criteria, the following data were extracted: the aims; summary of findings; sample and groups size; study setting and country; etiologies of liver disease; Length of ECG recording, and the equipment used; Methods of HRV analysis including data cleaning, analysed length, analysis software and indices calculated; The etiology of cirrhosis including alcohol, fatty, primary biliary cholangitis, viral and cryptogenic were also extracted (Tables 1 and 2).

For the survival prediction, studies that used HRV indices for survival analysis in cirrhosis were included in the mini-systematic review. Where reported, the sample size, follow-up time, mortality, HRV indices analysed, HRV indices that predicts mortality independently of MELD and Child-Pugh scores, HRV indices of survivors and non-survivors and hazard or odds ratios were extracted from the studies (Table 3). 


\section{Quality assessment}

Two authors independently assessed the quality of the methods used in the included studies. A modified version of the Newcastle Ottawa Scale (NOS) was used [33]. The assessment comprised 3 domains that evaluated selection, comparability and outcome techniques employed in the included studies. The domains have 6 subdomains (questions) each of which is scored with a star. Lower score ( $\leq 3$ stars) were considered as having high risk of bias (Table S1).

\section{Data synthesis}

A meta-analysis was computed to calculate the difference in HRV between patients with cirrhosis and healthy controls. Output was generated as forest plots of effect sizes of HRV indices between the groups using the Metan procedure in Stata/SE15. HRV indices reported as median and interquartile mode were transformed to mean and standard deviation according to $(17,18)$, while indices presented as natural log (LN) were transformed by finding exponents $\left(\mathrm{e}^{\mathrm{x}}\right)$ accordingly. For studies where day and night indices were reported, the data of the day were used.

The effect sizes in the form of standardized mean difference (SMD) of each of the reported indices were pooled using the Hedges' criteria (19). Random-effect or fixed effect model were used depending on between-studies heterogeneity and effect sizes presented as SMD with 95\% confidence intervals (CI) in $\mathrm{HRV}$ indices between the patients and heathy controls. The effect sizes were visualized as forest plots which include percentage weights and between-studies heterogeneity $\left(I^{2}\right.$ Statistic, $p$-value). The $I^{2}$ statistic measures the degree of heterogeneity between pooled studies and can be putatively interpreted as low, moderate or high when values are $25 \%, 50 \%$ or $75 \%$ respectively (20). The SMDs were interpreted according to the recommendations of Hopkins et al. whereby values $<0.2=$ trivial; $0.2-0.6=$ small, $0.6-1.2=$ moderate, 1.2-2.0 = large, 2.0-4.0 = very large, and > 4.0 = extremely large effect sizes (21) (Figures 1 and 2).

Meta-analysis of the survival analysis was not performed because of the small number of studies found. Further, some of these studies originated from the same centre and possibly involved the same set of patients. Also, the indices reported varies between studies as well as the follow-up time. 


\section{Results}

Our database search generated a total of 247 studies of which 67 were duplicates. Of the remaining 180 studies, a total of 30 studies were deemed potentially relevant according to the inclusion criteria. However, a full text review resulted in the exclusion of a further 16 papers to give 14 studies that fulfilled all criteria (Figure 1). For the mini systematic review, a total of 7 studies compared the HRV indices of patients with cirrhosis that survived and did not survive.

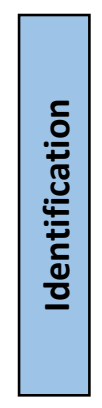

247 Records identified through searching of Databases
Medline $n=58$
PubMed $n=66$
EMBASE $n=123$

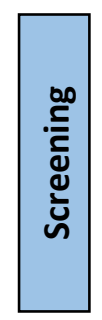

180 records after

duplicate removal

150 Records excluded as did not meet inclusion criteria:

Title duplicates $n=67$

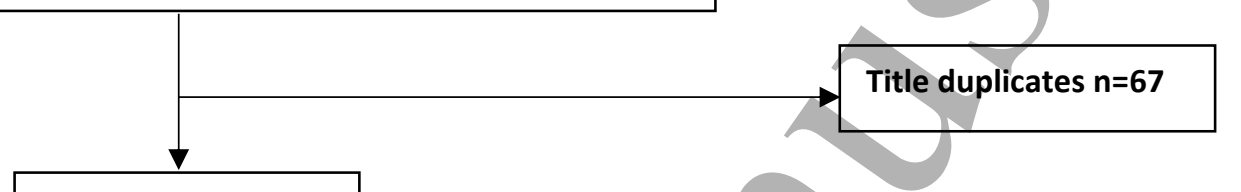

- 98 Unrelated Studies

- 25 HRV Tilt Tests

- 8 Non-Human

- 13 Reviews and Abstracts

- 6 Full text no available

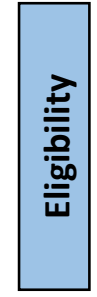

30 full-text articles assessed for eligibility

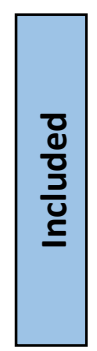

16 Full-text articles excluded:

- 5 No Control Group

- 6 Involves Interventions

- 1 Unclear HRV Calculations

- 4 Non-Cirrhotic Liver Disease

4 studies included in review

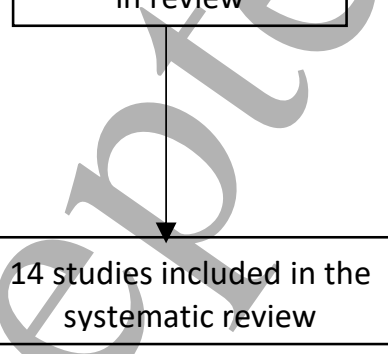

Figure 1 - Heart rate variability in patients with cirrhosis, systematic review according to the Preferred Reporting Items for Systematic Reviews and Meta-analyses diagram. 


\section{Description of included studies}

Table 1 presents the general characteristics of included studies while Table 2 contains the techniques used for ECG recording, HRV analysis and indices reported to be significantly different between the groups. Table 4 presents the definitions for the HRV indices. The 14 included studies comprise a total of 583 patients and 349 healthy matched controls with sample size ranging between 20 and 180 . All studies included are observational and conducted across 10 countries.

The risk of bias as assessed by the modified NOS scale showed that most studies have low risk of bias with none of the 14 studies scoring $\leq 3$ (Table S1). Overall, most studies reported a reduction in HRV indices except LF-HF ratio (LF: HF) which was reported to be both increased $[5,10]$ and decreased [11] in cirrhosis. Table S2 contains definitions and units of the indices of HRV.

The mini-systematic review included 7 studies involving a total of 437 patients. Of these, 104 (24\%) patients did not survive to the end of follow-up ( 3 to 24 months). All studies observed significant differences in HRV indices between the survivors and non-survivors (Table 3). 
Table 1 - General characteristics of included studies.

\begin{tabular}{|c|c|c|c|c|c|c|c|c|}
\hline Author & Aim & Conclusion & Country & Setting & $\begin{array}{l}\text { Liver } \\
\text { Disease } \\
\text { (Male) }\end{array}$ & $\begin{array}{l}\text { Control } \\
\text { (male) }\end{array}$ & Aetiology & $\begin{array}{l}\text { Child-Pugh } \\
\text { /Histological } \\
\text { Classification }\end{array}$ \\
\hline Ates F. et al. 2006 (22) & $\begin{array}{l}\text { To assess using HRV autonomic } \\
\text { dysfunction and its correlation with } \\
\text { severity and 2-year survival in cirrhotic } \\
\text { patients. }\end{array}$ & $\begin{array}{l}\text { (1) HRV time-domain indices significantly reduced in cirrhotic } \\
\text { patients compared to healthy subjects. (2) HRV indices also } \\
\text { significantly reduced in non-survivor vs survivors after } 2 \text { years of } \\
\text { follow-up. }\end{array}$ & Turkey & NR & $30(19)$ & $28(16)$ & $\begin{array}{l}\mathrm{HBV}=22 \\
\mathrm{HCV}=8\end{array}$ & $\begin{array}{l}A=5 \\
B=11 \\
C=14\end{array}$ \\
\hline Baratta L. et al. 2010 (23) & $\begin{array}{l}\text { To assess the effect on liver } \\
\text { transplantation (LT)) on autonomic } \\
\text { control of cardiac function in cirrhotic } \\
\text { patient using HRV. }\end{array}$ & $\begin{array}{l}\text { (1) HRV indices (SDNN and RMSSD) was reduced in cirrhotic } \\
\text { patients compared with healthy subjects. (2) LT corrected the } \\
\text { reduced SDNN but RMSSD and LF/HF remained unchanged. }\end{array}$ & Italy & outpatient & $30(20)$ & $27(14)$ & $\begin{array}{l}\mathrm{HBV}=4 \\
\mathrm{HCV}=14 \\
\text { Other (NASH, } \\
\text { Ethanol, } \\
\text { Mixed) }=12\end{array}$ & $\begin{array}{l}A=5 \\
B=18 \\
C=7\end{array}$ \\
\hline Coelho, L. et al. 2001 (24) & $\begin{array}{l}\text { To evaluate autonomic function in patient } \\
\text { with liver cirrhosis using } \mathrm{HRV} \text { and to } \\
\text { evaluate the relationship with severity }\end{array}$ & $\begin{array}{l}\text { (1) HRV is significantly reduced in chronic liver disease. (2) } \\
\text { Reduced HRV is correlated with severity of liver disease. (3) } \\
\text { Autonomic dysfunction is not related to the aetiology of liver } \\
\text { disease. (4) Markers of hepatocellular dysfunction are more } \\
\text { accurate predictor of autonomic dysfunction compared to } \\
\text { markers of cholestasis where SDNN correlated significantly with } \\
\text { prothrombin ( } r=0.64, p=0.001 \text { ) and serum albumin ( } r=0.40 \text {, } \\
p=0.05 \text { ) but not total bilirubin. }\end{array}$ & Portugal & NR & $22(11)$ & 20 & $\begin{array}{l}\text { Alcohol }=12 \\
\mathrm{HBV}+\mathrm{HCV}=6 \\
\text { Autoimmune }= \\
2 \\
\text { Others }=2\end{array}$ & $\begin{array}{l}A=6 \\
B=9 \\
C=7\end{array}$ \\
\hline Frokjaer V. G. et al. 2006 (25) & $\begin{array}{l}\text { To determine if autonomic dysfunction is } \\
\text { related to cerebral blood flow } \\
\text { autoregulation in cirrhotic patients. }\end{array}$ & $\begin{array}{l}\text { (1) Cerebral autoregulation of blood flow impaired in severe } \\
\text { cases of liver cirrhosis. (2) Impairment of cerebral autoregulation } \\
\text { correlated with autonomic dysfunction (3) severity of cirrhosis } \\
\text { correlated with degree of autonomic dysfunction (4) loss of } \\
\text { sympathetic innervation of cerebral vessels possibly linked with } \\
\text { cerebral autoregulation dysfunction in cirrhotic patients. }\end{array}$ & Denmark & outpatients & $14(9)$ & $11(5)$ & $\begin{array}{l}\text { Alcohol }=8 \\
\text { PBC }=4 \\
\text { Cryptogenic }=2\end{array}$ & $\begin{array}{l}A=5 \\
B=6 \\
C=3\end{array}$ \\
\hline Iga A. et al. 2003 (26) & $\begin{array}{l}\text { To assess autonomic abnormalities in } \\
\text { patient with Liver cirrhosis using 123- } \\
\text { metaiodobenzylguanidine } \\
\text { myocardial scintigraphy and HRV. }\end{array}$ & $\begin{array}{l}\text { Autonomic dysfunction is present in cirrhotic patients and can be } \\
\text { assessed by MIBG myocardial scintigraphy and HRV. }\end{array}$ & Japan & NR & $50(27)$ & $50(33)$ & $\begin{array}{l}\mathrm{HBV}=4 \\
\mathrm{HCV}=40 \\
\mathrm{HBV}+\mathrm{HCV}=2 \\
\mathrm{PBC}=4\end{array}$ & $\begin{array}{l}A=20 \\
B=12 \\
C=18\end{array}$ \\
\hline Ko F.Y. et al. 2013 (27) & $\begin{array}{l}\text { To assess the relationship between } \\
\text { psychological distress and clinical } \\
\text { presentations of cirrhosis using } \\
\text { biochemical and/physiological } \\
\text { markers. }\end{array}$ & $\begin{array}{l}\text { (1) Psychological distress was correlated with increased serum } \\
\text { aspartate aminotransferase (AST), and reduced autonomic } \\
\text { control of the heart (HRV). (2) Inflammation may have a role to } \\
\text { play in cirrhotic psychological distress. }\end{array}$ & China & outpatients & $125(73)$ & $55(29)$ & $\begin{array}{l}\text { Alcohol }=14 \\
\mathrm{HBV}+\mathrm{HCV}=83 \\
\text { Autoimmune }= \\
5 \\
\text { Parasites }=5 \\
\text { Others }=18\end{array}$ & $\begin{array}{l}A=43 \\
B=58 \\
C=24\end{array}$ \\
\hline Lazzeri C. et al. 1997 (28) & $\begin{array}{l}\text { To assess autonomic neuropathy in } \\
\text { patients with non-alcoholic cirrhosis with } \\
\text { ascites. }\end{array}$ & $\begin{array}{l}\text { Ascitic patients with non-alcoholic cirrhosis have autonomic } \\
\text { neuropathy compared with healthy controls and this is } \\
\text { associated with significant difference in HRV indices between the } \\
\text { groups. }\end{array}$ & Italy & outpatients & $12(7)$ & 12 & $\begin{array}{l}\mathrm{HBV}=2 \\
\mathrm{HCV}=8 \\
\text { Cryptogenic }=2\end{array}$ & $\begin{array}{l}A=0 \\
B=5 \\
C=7\end{array}$ \\
\hline Mani A.R. et al. 2008 (13) & $\begin{array}{l}\text { To assess the relationship between indices } \\
\text { of HRV, hepatic encephalopathy and } \\
\text { systemic inflammation in cirrhotic } \\
\text { patients }\end{array}$ & $\begin{array}{l}\text { (1) Reduced long term HRV in cirrhotic patients compared with } \\
\text { healthy subjects. (2) HRV negatively correlated with degree of } \\
\text { neuropsychiatric impairment. (3) } 8 \% \text { increased relative risk of } \\
\text { death for every } 1 \mathrm{~ms} \text { drop in HRV index (4) Indices of HRV and } \\
\text { neuropsychiatric performance significantly correlated with level } \\
\text { of plasma IL6. }\end{array}$ & UK & $\begin{array}{l}\text { inpatients } \\
\text { (14) } \\
\text { outpatients } \\
\text { (66) }\end{array}$ & $80(53)$ & $11(5)$ & $\begin{array}{l}\text { Alcohol }=65 \\
\mathrm{HBV}+\mathrm{HCV}=7 \\
\text { Mixed } \\
\text { (Various) }=9\end{array}$ & $\begin{array}{l}A=51 \\
B=13 \\
C=16\end{array}$ \\
\hline Milovanovic B. et al. 2009 (29) & $\begin{array}{l}\text { To analyse risk predictors of sudden } \\
\text { cardiac death }(\mathrm{SCD}) \text { related to autonomic } \\
\text { dysfunction in alcohol-related cirrhotic } \\
\text { patients. }\end{array}$ & $\begin{array}{l}\text { (1) Patients with ARLD are susceptible to autonomic dysfunction } \\
\text { (56\%). (2) ARLD patients also have lower HRV indices (SDNN, } \\
\text { SDANN, TINN, LF, and HF), serious arrhythmia, prolonged QTC } \\
\text { and abnormal Poincare plot. (3) QTc inversely correlated with }\end{array}$ & Serbia & inpatients & $25(20)$ & $19(15)$ & Alcohol $=25$ & NR \\
\hline
\end{tabular}


$\operatorname{lnLF}, \operatorname{InHF}(r=-0.53, r=-0.47 ; p<0.05)$ while Lown class correlated with autonomic function $(r=-0.64 ; p=0.05)$.

\begin{tabular}{|c|c|c|c|c|c|c|c|c|}
\hline Miyajima H. et al. 2001 (30) & $\begin{array}{l}\text { To assess the effect of portal blood flow } \\
\text { volume and autonomic nervous function } \\
\text { on abnormal gastric motility in cirrhotic } \\
\text { patients. }\end{array}$ & $\begin{array}{l}\text { (1) Autonomic dysfunction correlated with abnormal gastric } \\
\text { motility in cirrhotic patients (2) Decreased gastric motility may } \\
\text { result from abnormalities in autonomic function in cirrhotic } \\
\text { patients }\end{array}$ & Japan & NR & $27(19)$ & $20(13)$ & $\begin{array}{l}\text { Alcohol }=1 \\
\mathrm{HBV}=5 \\
\mathrm{HCV}=21\end{array}$ & $\begin{array}{l}A=7 \\
B+C=20\end{array}$ \\
\hline Moller S. et al. 2012 (31) & $\begin{array}{l}\text { To assess sympathetic control of cardiac } \\
\text { function in cirrhosis using mIBG } \\
\text { scintigraphy and relate this to } \\
\text { cardiovascular functions }\end{array}$ & $\begin{array}{l}\text { (1) Cirrhotic patients have significantly reduced HRV and } \\
\text { baroreflex activity. (2) Reduction in HRV and baroreflex } \\
\text { correlated significantly with abnormal cardiac sympathetic } \\
\text { nervous activity measured by catecholamine uptake by mIBG. }\end{array}$ & Denmark & outpatients & $10(5)$ & $10(5)$ & Alcohol $=10$ & NR \\
\hline Nagasako C.K. et al. 2009 (32) & $\begin{array}{l}\text { To assess autonomic dysfunction in non- } \\
\text { alcoholic cirrhosis and the relationship } \\
\text { with disturbed intestinal transit time, as } \\
\text { well as severity and prognosis using HRV. }\end{array}$ & $\begin{array}{l}\text { (1) HRV indices (HF, InHF, LF, InLF, pNN50) was lower in cirrhotic } \\
\text { patients (Child B) patients compared with child A and control } \\
\text { subjects. (2) HRV indices correlated significantly with the risk of } \\
\text { hepatic encephalopathy in cirrhotic patients. }\end{array}$ & Brazil & NR & $32(12)$ & $21(12)$ & $\begin{array}{l}\mathrm{HCB}=16 \\
\mathrm{PBC}=6 \\
\text { Cryptogenic }=6 \\
\text { Others }=4\end{array}$ & $\begin{array}{l}A=13 \\
B=19 \\
C=0\end{array}$ \\
\hline Negru R.D. et al. 2015 (33) & $\begin{array}{l}\text { To assess the use of HRV as a marker of } \\
\text { autonomic dysfunction and severity in } \\
\text { cirrhotic patients. }\end{array}$ & $\begin{array}{l}\text { (1) HRV detected autonomic dysfunction in cirrhotic patients. (2) } \\
\text { Aetiology of liver cirrhosis is linked with different types of } \\
\text { autonomic dysfunctions. (3) HRV parameters correlated } \\
\text { significantly with severity of liver cirrhosis as assessed by Child- } \\
\text { Pugh scores. }\end{array}$ & Romania & inpatients & $52(27)$ & $30(15)$ & $\begin{array}{l}\text { Alcohol }=25 \\
\mathrm{HBV}=6 \\
\mathrm{HCV}=17 \\
\text { Mixed }=4\end{array}$ & $\begin{array}{l}A=30 \\
B=8 \\
C=14\end{array}$ \\
\hline Satti R. et al. 2019 (14) & $\begin{array}{l}\text { To extend the Poincare plot by introducing } \\
\text { a sequential lag in the correlation } \\
\text { computation and to evaluate the } \\
\text { relationship with the severity and survival } \\
\text { of cirrhotic patients. }\end{array}$ & $\begin{array}{l}\text { (1) Traditional SD1 and SD2 correlated strongly with severity of } \\
\text { liver cirrhosis. (2) Lagged SD1 and SD2 correlated significantly } \\
\text { with liver disease severity. However, extended SD1 did not } \\
\text { predict mortality independently of MELD. (3) SD2 predicted } \\
\text { survival of cirrhotic patients independent of MELD. }\end{array}$ & Italy & Outpatients & 74 & 35 & NR & NR \\
\hline
\end{tabular}

vs, versus; HRV, Heart Rate Variability; ARLD, Alcohol-Related Liver Disease; NALD, Non-Alcoholic Liver Disease (including virus-linked liver diseases); PBC, Primary Biliary Cholangitis; IL6, Interleukin-6; LT, Liver Transplantation; In, Natural Logarithm; QTC, Q-T complex describing time Interval between the start of Q-wave and T-wave of an ECG recording; HCV, Hepatitis C Virus; MELD, Model for End-Stage Liver Disease; NN Interval, time lapse between consecutive QRS complexes of ECG recording; SDNN, Standard deviation of NN intervals; SDANN, Standard deviation of the average NN intervals for each 5-minute segments deduced from a 24-hour ECG recoding; pNN50, Percentage of successive RR intervals that vary by more than 50ms; RMSSD, Root mean square of differences in successive NN interval; TINN, Triangular Interpolation of the NN intervals' histogram; LF, Low Frequency; HF, High Frequency; SD1, Poincare plot Standard Deviation perpendicular to the line of identity; SD2, Poincare plot Standard Deviation along the line of identity; ApEn, Approximate Entropy; NR, Not Reported.

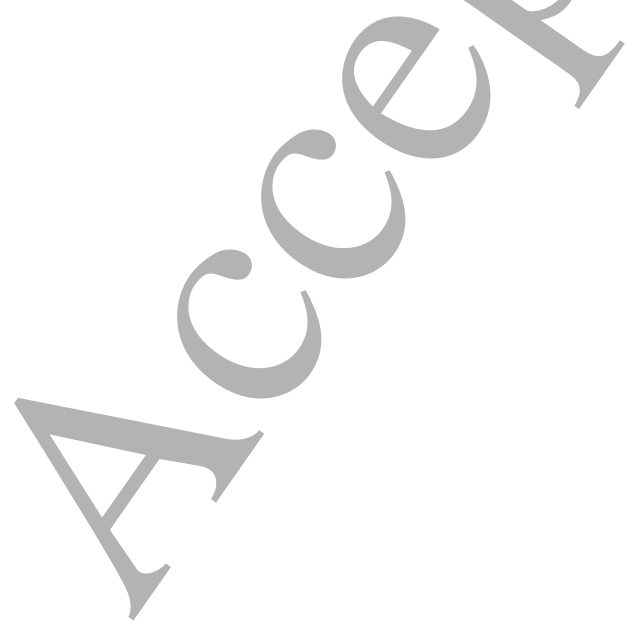


Table 2 - ECG recording and HRV analysis techniques of included studies.

\begin{tabular}{|c|c|c|c|c|c|c|c|c|}
\hline $\begin{array}{l}3 \text { Author } \\
4\end{array}$ & $\begin{array}{l}\text { Sampling } \\
\text { Time/len } \\
\text { gth }\end{array}$ & Analysis time/length & Equipment (Manufacturer) & $\begin{array}{l}\text { Sampl } \\
g \quad \mathrm{Ra} \\
(\mathrm{Hz})\end{array}$ & Analysis Software & $\begin{array}{l}\text { Data processed } \\
\text { (filtering/ } \\
\text { correction/ } \\
\text { Selection/manu } \\
\text { al editing etc.) }\end{array}$ & HRV Indices Measures & Significant HRV indices $(p<0.05)$ \\
\hline Ates F. et al. 2006 (22) & 24 hours & 24 hours & $\begin{array}{l}\text { HolterWin P-V Version } 5.40 \text { Plus; Diagnostic } \\
\text { Monitoring, Santana, CA }\end{array}$ & NR & $\begin{array}{l}\text { HolterWin P-V Version } 5.40 \text { Plus; Diagnostic } \\
\text { Monitoring, Santana, CA. (Commercial). }\end{array}$ & Yes & mean NN, SDNN, SDANN, RMSSD, pNN50 & $\begin{array}{l}\text { mean NN, SDNN, SDANN, RMSSD, } \\
\text { pNN50 }\end{array}$ \\
\hline $\begin{array}{l}8 \text { Baratta L. et al. } 2010 \\
9 \text { (23) }\end{array}$ & 24 hours & NR & $\begin{array}{l}\text { Accuplus } 363 \text { (Del Mar Medical System, } \\
\text { Irvine, CA, USA) }\end{array}$ & & NR & Yes & SDNN, RMMSD, HF, LF, LF/HF & SDNN. RMSSD, HF(night) \\
\hline $10 \begin{array}{l}\text { Coelho, L. et al. } 2001 \\
\text { (24) }\end{array}$ & 24 hours & 24 hours & NR & NR & NR & No & SDNN, pNN50, VLF, LF, HF, LF/HF & Reduced SDNN, pNN50, VLF, LF, HF \\
\hline $\begin{array}{l}11 \text { Frokjaer V. G. et al. } \\
122006(25)\end{array}$ & 24 hours & 24 hours & $\begin{array}{l}\text { Portable Cardio recorder (Spacelab 90208, } \\
\text { USA }\end{array}$ & NR & Spacelab Medical FT3000. (Commercial). & Yes & SDNN, RMSSD, VLF, LF, HF, TP. & SDNN, VLF, LF, HF, TP \\
\hline $\begin{array}{l}13^{\text {Iga A. et al. } 2003(26)} \\
14\end{array}$ & 24 hours & 512 heartbeats & $\begin{array}{l}\text { SM-50 (Fukuda Denshi Corporation, Tokyo, } \\
\text { Japan) + DWM-900OH Workstation (Fukuda } \\
\text { Denshi Corporation) }\end{array}$ & NR & $\begin{array}{l}\text { MemCalc Ver2.5 (Suwa Trust, Tokyo, Japan). } \\
\text { (Commercial). }\end{array}$ & No & $L F, H F, L F / H F$ & LF, HF, LF/HF \\
\hline $15^{\text {Ko F.Y. et al. } 2013 \text { (27) }}$ & 5 minutes & 5 minutes & Ad hoc/customized & 256 & $\begin{array}{l}\begin{array}{l}\text { Open-Source } \\
\text { (Commercial). }\end{array} \quad \text { Software } \quad \text { (Physionet). } \\
\text {. }\end{array}$ & NR & $\begin{array}{l}\text { SDNN, RMMSD, LnHF, LnLF, InVLF, LF/HF, } \\
\text { DFA } \alpha 1 \text {, DFA } \alpha 2\end{array}$ & SDNN, RMSSD, InHF, InLF, DFA $\alpha 1$ \\
\hline $\begin{array}{l}16_{\text {Lazzeri C. et al. } 1997} \\
17 \text { (28) } \\
18\end{array}$ & 24 hours & $\begin{array}{l}512 \text { RRI (Frequency } \\
\text { Domain), } 24 \text { hours (Time } \\
\text { Domain). }\end{array}$ & $\begin{array}{l}\text { ELATEC } \\
\text { Medical, Segrate. Italy) }\end{array}$ & NR & $\begin{array}{l}\text { HRV module for ELATEC 1.0. (ELA Medical, } \\
\text { Segrate. Italy). (Commercial). }\end{array}$ & Yes & $\begin{array}{l}\text { Mean RR, SDNN, SDANN, RMSSD, pNN50, } \\
\text { TP, LF, HF, LF/HF. }\end{array}$ & $\begin{array}{l}\text { SDNN, SDANN, RMSSD, pNN50, LF, } \\
\text { HF }\end{array}$ \\
\hline 19 Mani A.R. et al. 2008 & $\begin{array}{l}10 \\
\text { minutes }\end{array}$ & 5 minutes & NR & 256 & Lab-built (Ad hoc) & Yes & SDNN, LF, HF, LF/HF, SD1, SD2, SampEn & SDNN, LF, HF, SD1, SD2, SampEn \\
\hline $\begin{array}{l}20 \text { Milovanovic B. et al. } \\
212009 \text { (29) }\end{array}$ & 24 hours & 24 hours & 3 Leads ECG equipment (Biosensor, USA) & 1000 & Biosensor, USA. (Commercial). & Yes & $\begin{array}{l}\text { Mean RR, SDNN, SDANN, RMSSD, TP, HF, } \\
\text { LF, LF/HF, InHF, InLF, TINN }\end{array}$ & SDNN, SDANN, TINN, InHF, InLF. \\
\hline 22 Miyajima H. et al. 2001 & NR & 512 heartbeats & $\begin{array}{l}\text { SM-50 (Fukuda Denshi Corporation, Tokyo, } \\
\text { Japan) }\end{array}$ & NR & $\begin{array}{l}\text { DWM-9000H (Fukuda Denshi Corporation, } \\
\text { Tokyo, Japan). (Commercial). }\end{array}$ & NR & $\mathrm{LF}, \mathrm{HF}, \mathrm{LF} / \mathrm{HF}$ & $H F, L F / H F$ \\
\hline 23 Moller S. et al. 2012 & $\begin{array}{l}50 \\
\text { minutes }\end{array}$ & 50 minutes & $\begin{array}{l}\text { Task Force Monitor (TFM) (CNSystems, } \\
\text { Graz, Austria) }\end{array}$ & NR & $\begin{array}{l}\text { Task Force Monitor (TFM) (CNSystems, Graz, } \\
\text { Austria) }\end{array}$ & NR & $V L F, L F, H F, L F / H F$ & $L F, H F, L F / H F$ \\
\hline $\begin{array}{l}25_{2009(32)} \\
26\end{array}$ & 24 hours & $\begin{array}{l}\text { Frequency Domain }=5 \\
\text { minutes }(X 72) \text { Time } \\
\text { Domain }=24 \text { hours }\end{array}$ & $\begin{array}{l}\text { DynamicsR } 300 \quad \text { (Cardios Sistemas,São } \\
\text { Paulo, Brazil) }\end{array}$ & NR & $\begin{array}{l}\text { Commercial software (DMI Cardios Sistemas, } \\
\text { São Paulo, Brazil). (Commercial). }\end{array}$ & NR & $\begin{array}{l}\text { Mean NN, SDNN, RMSSD, pNN50, TP, LF, } \\
\text { InLF, HF, InHF, LF/HF }\end{array}$ & $\begin{array}{l}\text { SDNN, pNN50, TP, HF, InHF, LF, InLF, } \\
\text { LF/HF }\end{array}$ \\
\hline 27 Negru R.D. et al. 2015 & 24 hours & 24 hours & $300-3 \mathrm{~A}$ recorders (DMS - USA) & 128 & 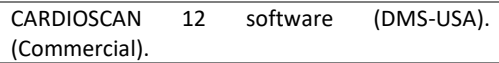 & Yes & $\begin{array}{l}\text { SDNN, SDANN, SDNN index, RMSSD, } \\
\text { pNN50, TP, LF, HF, VLF }\end{array}$ & SDNN, SDNN index, SDANN, TP, VLF \\
\hline 28 Satti R. et al. 2019 (14) & $\begin{array}{l}10 \\
\text { minutes }\end{array}$ & 8 minutes & Chart 5 (AD-Instrument, Australia) & 256 & Lab-built (Ad hoc) & Yes & $\begin{array}{l}\text { Traditional SD1 and SD2 and r (Pearson } \\
\text { Correlation); lagged SD1 and SD2 and } r \\
\text { (Pearson Correlation) }\end{array}$ & SD1, SD2, r (Pearson Correlation) \\
\hline
\end{tabular}

$E C G$, Electrocardiograph; RRI, RR interval describing the time lapse between consecutive $R$-waves of an ECG recording; NN Interval, time lapse between consecutive QRS complexes of ECG recording; SDNN, Standard deviation of NN intervals; SDANN, Standard deviation of the average NN intervals for each 5-minute segments deduced from a 24-hour ECG recoding; pNN50, Percentage of successive RR intervals that vary by more than 50ms; RMSSD, Root mean square of differences in successive NN interval; TINN, Triangular Interpolation of the NN intervals' histogram; TP, Total Power; VLF Very Low Frequency; LF, Low Frequency; HF, High Frequency; LF/HF, Ratio of LF to HF; SD1, Poincare plot Standard Deviation perpendicular to the line of identity; SD2, Poincare plot Standard Deviation along the line of identity; ApEn, Approximate Entropy; SampEn, Sample Entropy; DFA $\alpha 1$, Short-term fluctuation of Detrended Fluctuation Analysis; DFA $\alpha 2$, Long-term fluctuation of Detrended Fluctuation Analysis; NR, Not Reported.

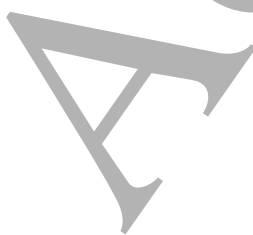




\section{HRV Time Domains}

A total of 13 studies observed significant differences in HRV time domains between patients with cirrhosis and matched controls. The time domains reported include standard deviation of NN intervals (SDNN), SDNN Index, standard deviation of the average NN intervals for each 5 min segment of a $24 \mathrm{~h}$ ECG recording (SDANN), root mean square of successive NN interval (RMSSD) and percentage of NN intervals that differ by $50 \%$ (pNN50). Significant effect sizes were observed for each of the pooled time domain indices (SDNN, SDANN, RMSSD and pNN50\%) which were significantly higher in the healthy controls. Overall, the betweenstudies heterogeneities were significantly high in all the pooled HRV time domains (Figures 2a-d).

\section{○ SDNN}

SDNN is the standard deviation of normal/non-ectopic RR intervals (NN) and is translated as the measure of the overall influence of autonomic nervous system on the variation of heart rhythm $(34,35)$. A total of 9 studies reported significant reduction in SDNN in cirrhosis $(13,22,24,25,27-29,32,33)$. Eight of the 9 studies presented SDNN as mean ( $\pm S D$ ) while one study (32) presented the median SDNN with no interquartile range (Table S3). This study was excluded from the effect size computation. A very large effect size was observed with significantly higher SDNN in healthy control compared with patients with cirrhosis $[\mathrm{SMD}(95 \% \mathrm{Cl})=3.41$ $(2.24,4.58)]$; Figure 2a]. This translates to noticeable dysregulation of the autonomic control of the cardiac rhythm in patients with cirrhosis.

\section{○ SDNN Index}

SDNN Index represents the average of all (288) 5 minutes-SDNNs of a 24-hour ECG recording. Physiologically, SDNN index has been linked with the overall autonomic control of heart rhythm $(34,35)$. Significant difference in the SDNN index was reported in only one of the included studies with a higher index and intact autonomic cardiac control in healthy controls (mean \pm SD $=56.50 \pm 17.04$ ) compared with the patients (mean \pm SD $=43.83 \pm 15.66$; Table S4) (33).

\section{○ SDANN}

SDANN is the standard deviation of all (288) averages of 5-minute NN intervals of a 24-hour ECG recording. SDANN is physiologically similar to SDNN in that it provides a measure of autonomic regulation of the heart rhythm $(34,35)$. Three studies reported a significant reduction in SDANN due to cirrhosis (Table S5) $(22,28$, 33). A significantly higher SDANN was observed in healthy controls compared with patients with cirrhosis with a very large difference between the groups $[\operatorname{SMD}(95 \% \mathrm{Cl})=2.54(0.81,4.27)$; Figure $2 b]$.

\section{○ RMSSD}

Root mean square of successive NN intervals is the square root of the mean of squared differences in consecutive NN intervals. RMSSD has been linked with vagal influence on the heart rhythm and is used as an 
index of respiratory sinus arrhythmia (RSA) $(34,35)$. Overall, 3 studies reported significant alteration in RMSSD in the patients compared with healthy controls (Table S6) $(22,27,28)$. There was significantly higher RMSSD in the control group with a large difference between the groups $[\mathrm{SMD}(95 \% \mathrm{Cl})=1.60(0.73,2.47)$; Figure 2c]. This can be interpreted as marked reduction in vagal control of the heart rhythm due to cirrhosis.

\section{○ pNN50}

Percentage of the NN intervals that differ from eachother by more than $50 \mathrm{~ms}$. The pNN50 indexes parasympathetic influence on heart rhythm and provides a comparatively less accurate assessment of RSA compared with the $\operatorname{RMSSD}(34,35)$. Further, 4 of the pooled studies found significant reduction in pNN50 in cirrhosis compared with healthy control $(22,24,28,32)$. One of the studies reported median pNN50 without the interquartile range and was not included on the analysis (Table S7) (32). Indeed, lower RMSSD was reported in the patients compared with the control groups with a very large effect size between the group $[\operatorname{SMD}(95 \% \mathrm{Cl})=2.54(1.21,3.87)$; Figure $2 \mathrm{~d}]$.

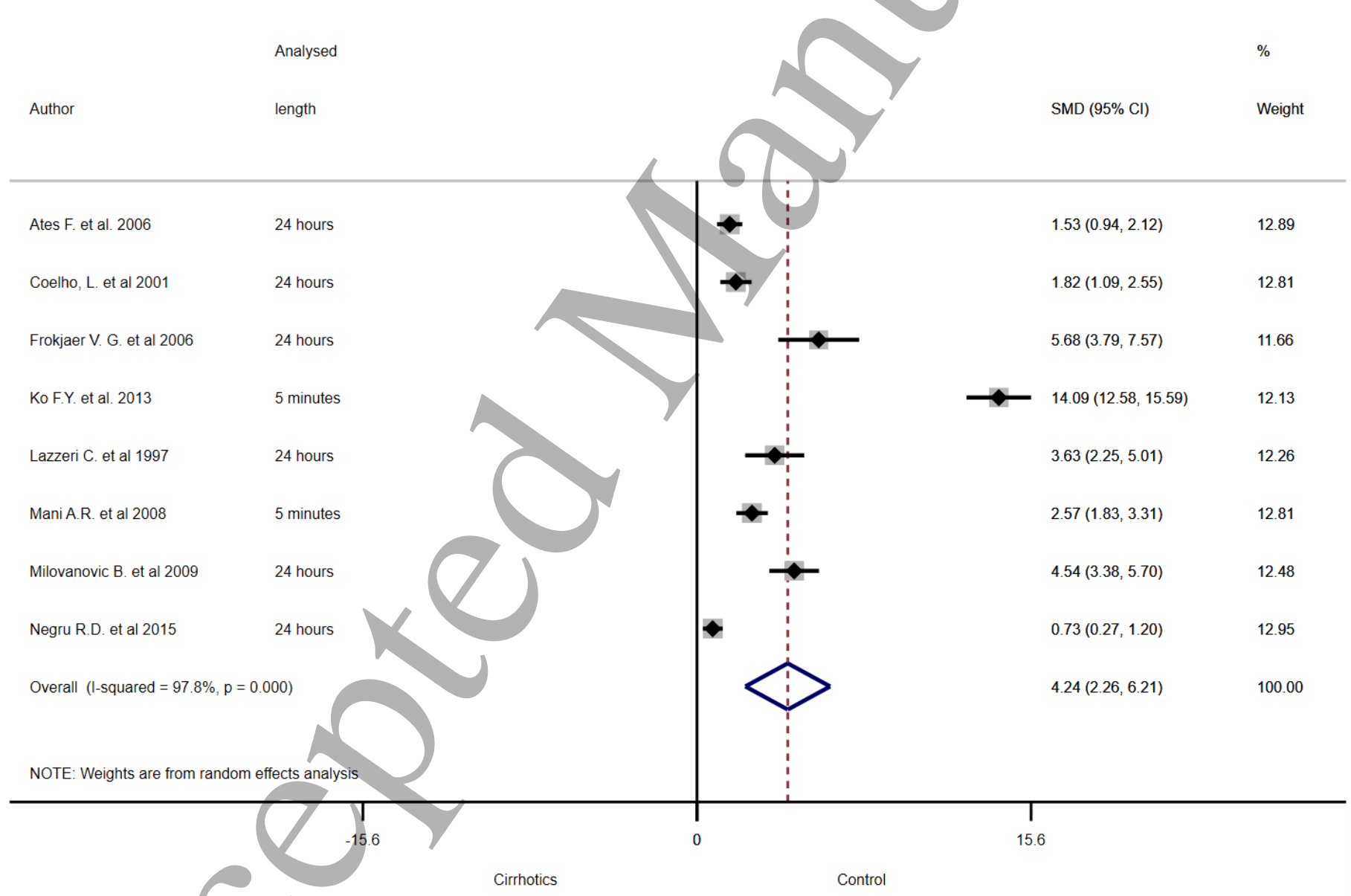

Figure 2a 


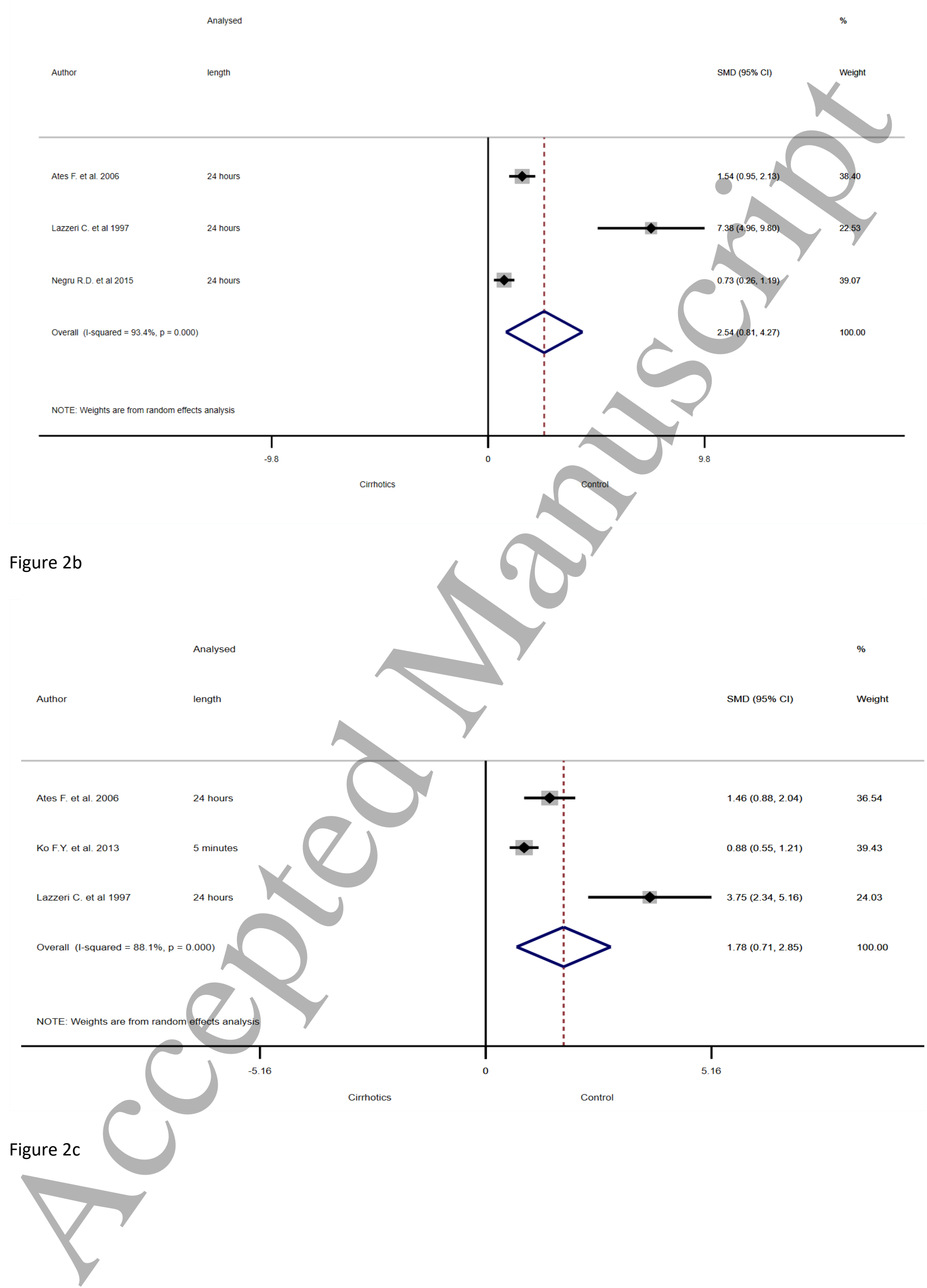




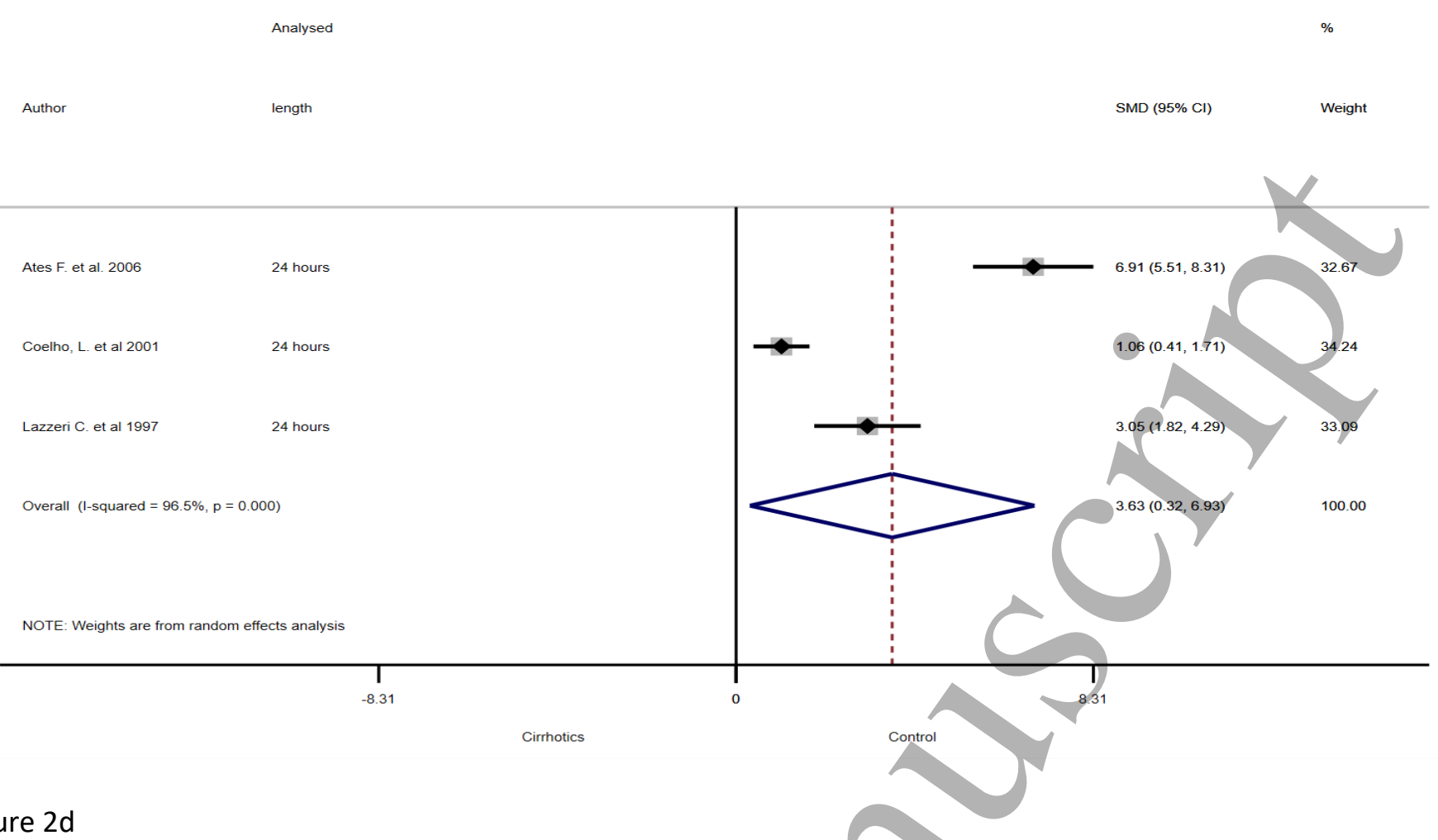

Figure $2 d$

Figure $\mathbf{2}(\mathbf{a}, \mathbf{b}, \mathbf{c}$ and $\mathbf{d})$. Forest plot for the standardized mean differences (SMD) in HRV time domain indices: SDNN (2a), SDANN (2b), RMSSD (2c) and pNN50 (2d) between patients with liver diseases and matched healthy controls. Hedges' $\mathrm{G}$ effect size estimates were calculated with $95 \%$ confidence interval and computed using random effect model. Continuous horizontal lines and diamonds width represents $95 \%$ confidence interval, and the diamonds centre and vertical red dotted line indicates the pooled random effect sizes. 


\section{HRV Frequency Domain}

HRV Frequency domains represent the various frequency bands resulting from autoregressive (AR) or Fast Fourier Transformation (FFT) of the NN variations. Ten of the included studies reported significant difference in HRV frequency domains between patients with cirrhosis and healthy controls. Indices reported include total power (TP), high frequency (HF), low frequency (LF), very low frequency (VLF), and LF/HF ratio (HF: LF). The between-studies heterogeneity as measured by Chi-square was significantly high in pooled HF and LF (Figures $3 b$ and $3 c$ ). Thus, random effect model was employed. Fixed effect model was used for pooling TP and VLF as the between studies heterogeneities were significantly low (Figures 3a and 3d).

\section{○ Total Power (TP)}

Total power represents the aggregate energy in all the frequency bands (ULF, VLF, LF, and HF) of an ECG recording $(34,35)$. Two studies reported significantly reduced TP in cirrhosis $(25,33)$. All reported TP were analysed for 24 hours ECG recordings and reported as natural log in one of the included studies (25) (Table S8). There was an overall higher TP observed in controls compared with the patients. A moderate effect size was observed between the group $[\operatorname{SMD}(95 \% \mathrm{Cl})=0.62(0.23,1.02)$; Figure 3a].

\section{O High Frequency (HF)}

High frequency is the power within the $0.15 \mathrm{~Hz}-0.4 \mathrm{~Hz}$ frequency band of an ECG recording. The HF represents the parasympathetic control of the heart rhythm and the variation linked with the respiratory sinus arrhythmia (RSA) $(34,35)$. A total of 9 studies reported significant difference in HRV high frequency between the patients and controls $(13,23,25-31)$. Of these, 8 studies reported reduced HF while 1 study reported an increased HF in cirrhosis (28) (Table S9). This study was not included in the data analysis because the model used does not correct for the difference in direction of effects (36). HF in healthy controls was observed to be higher compared with the patients, with an "extremely large" effect size between the groups $[\operatorname{SMD}(95 \% \mathrm{Cl})=4.36(1.94,6.77)$; Figure $3 \mathrm{~b}]$. This translates as an easily discernible dysregulation in vagal control of the heart rhythm in cirrhosis.

\section{○ Low Frequency (LF)}

Low frequency domain represents the power within $0.04-0.15 \mathrm{~Hz}$ frequency band of an ECG recording. The LF correlates strongly with baroreflex influence on the heart rhythm and is associated with both sympathetic and parasympathetic nervous controls $(34,35)$. Eight studies reported significantly different LF between the patients and healthy controls (Table S10) $(13,25-29,31)$. Low frequency power was observed to be significanlty lower in cirrhosis compared with control with an extremely large difference observed in the effect size $[\mathrm{SMD}(95 \% \mathrm{Cl})=5.49(2.32,8.67)$; Figure $3 c]$. Thus, a marked reduction in response of the heart rhythm to the the baroreflex loop which may be attributed to cirrhosis. 


\section{○ery Low frequency (VLF)}

Very low frequency represents the power in the $0.0033-0.04 \mathrm{~Hz}$ frequency band of an ECG recording. While uncertainty exists in the physiological factors responsible for the VLF band, it has been strongly linked with the renin-angiotensin system, thermoregulation and endothelial factors $(34,35)$. Two studies reported significant difference in 24-hour VLF between healthy controls and cirrhotic patients (Table S11) $(25,33)$. Healthy control group were observed to have significantly higher VLF compared with patients with cirrhosis. The effect size for VLF between the group was moderate $[\operatorname{SMD}(95 \% \mathrm{Cl})=0.73(0.32,1.13)$; Figure $3 d]$. This can be translated as a reasonably observable stronger response of the heart rhythm to renin-angiotensin system, thermoregulation and endothelial factors in healthy controls compared with the patients with cirrhosis.

○ Low Frequency - High Frequency Ratio (LF: HF)

The ratio of low frequency power to high frequency power of an ECG recording. The LF: HF is traditionally translated as the measure of the sympatho-vagal balance because LF and HF had been hypothesised as measures of purely sympathetic and parasympathetic cardiac controls respectively $(34,35)$. However, this notion was challenged when it was observed that LF is influenced by both arms of the autonomic nervous system (37). A total of 3 studies reported significant difference in LF: HF between the patients and controls $(26,30,31)$. Of these, 2 studies reported increase LF:HF in patients with cirrhosis $(26,30)$ and were pooled (Table S12). However, no significant effect size exist between the groups [i.e. test that SMD $=0: z=2.89 p$ $=0.004]$.

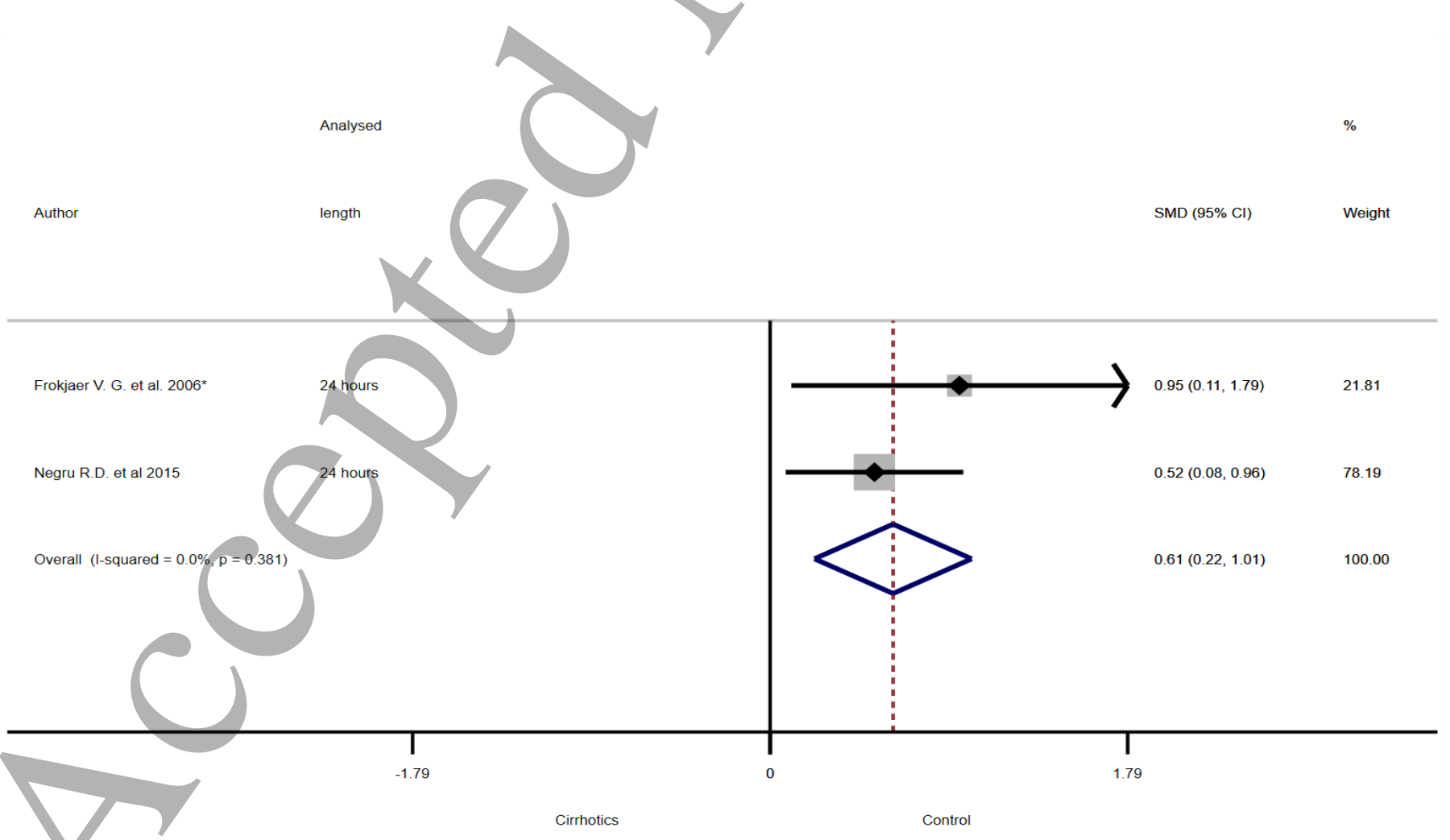

Figure 3a 


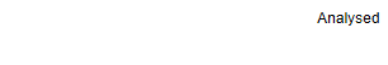

Author length

$\operatorname{SMD}(95 \% \mathrm{Cl})$

Weight

\begin{tabular}{|c|c|}
\hline Baratta L. et al. 2010 & NS \\
\hline Frokjaer V. G. et al. $2006^{*}$ & 24 hours \\
\hline Iga A. et al. $2003^{* \star * x}$ & 512 heartbeats \\
\hline Ko F.Y. et al. $2013^{\text {** }}$ & 5 minutes \\
\hline Lazzeri C. et al. $1997^{\mathrm{thn}}$ & 512 heartbeats \\
\hline Mani A.R. et al 2008 & 5 minutes \\
\hline Milovanovic B. et al. $2009^{* *}$ & 24 hours \\
\hline Miyajima H. et al. 2001 & 512 heartbeats \\
\hline Moller S. et al. $2012^{*}$ & 50 minutes \\
\hline
\end{tabular}

Overall (1-squared $=98.4 \%, p=0.000)$

NOTE: Weights are from random effects analysis

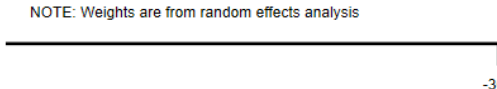

Figure $3 b$
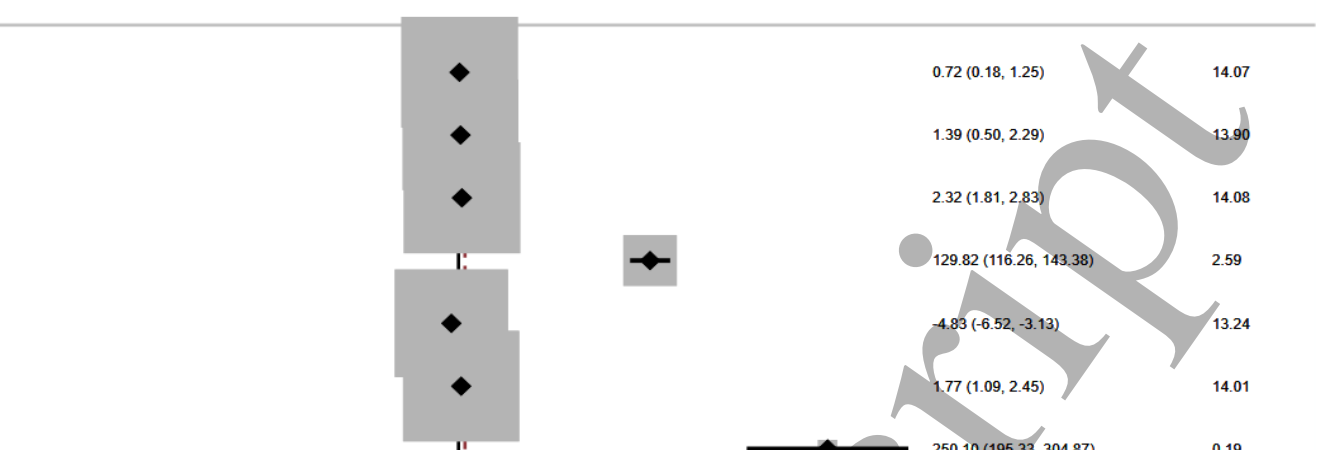

32

33

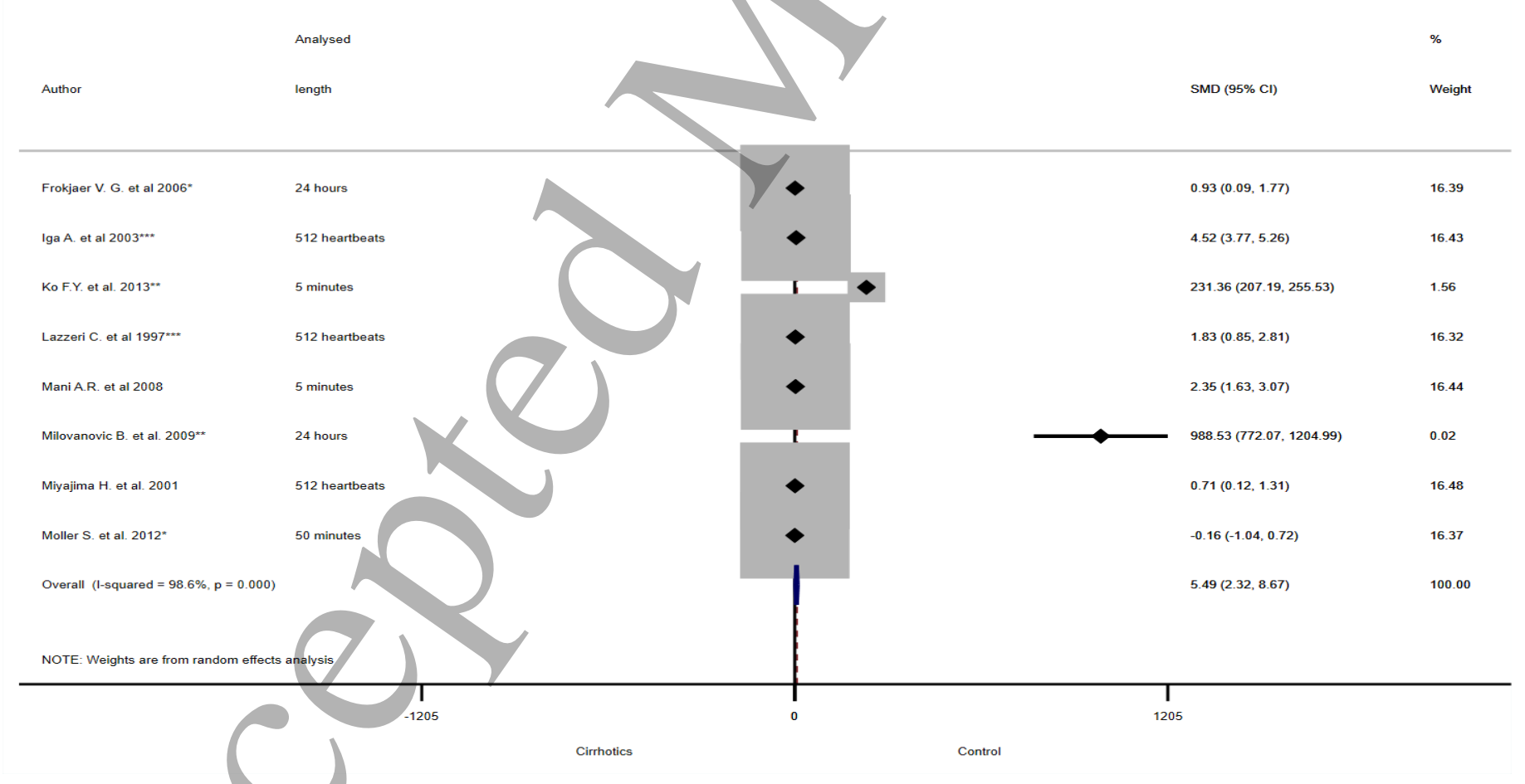

Figure $3 c$ 


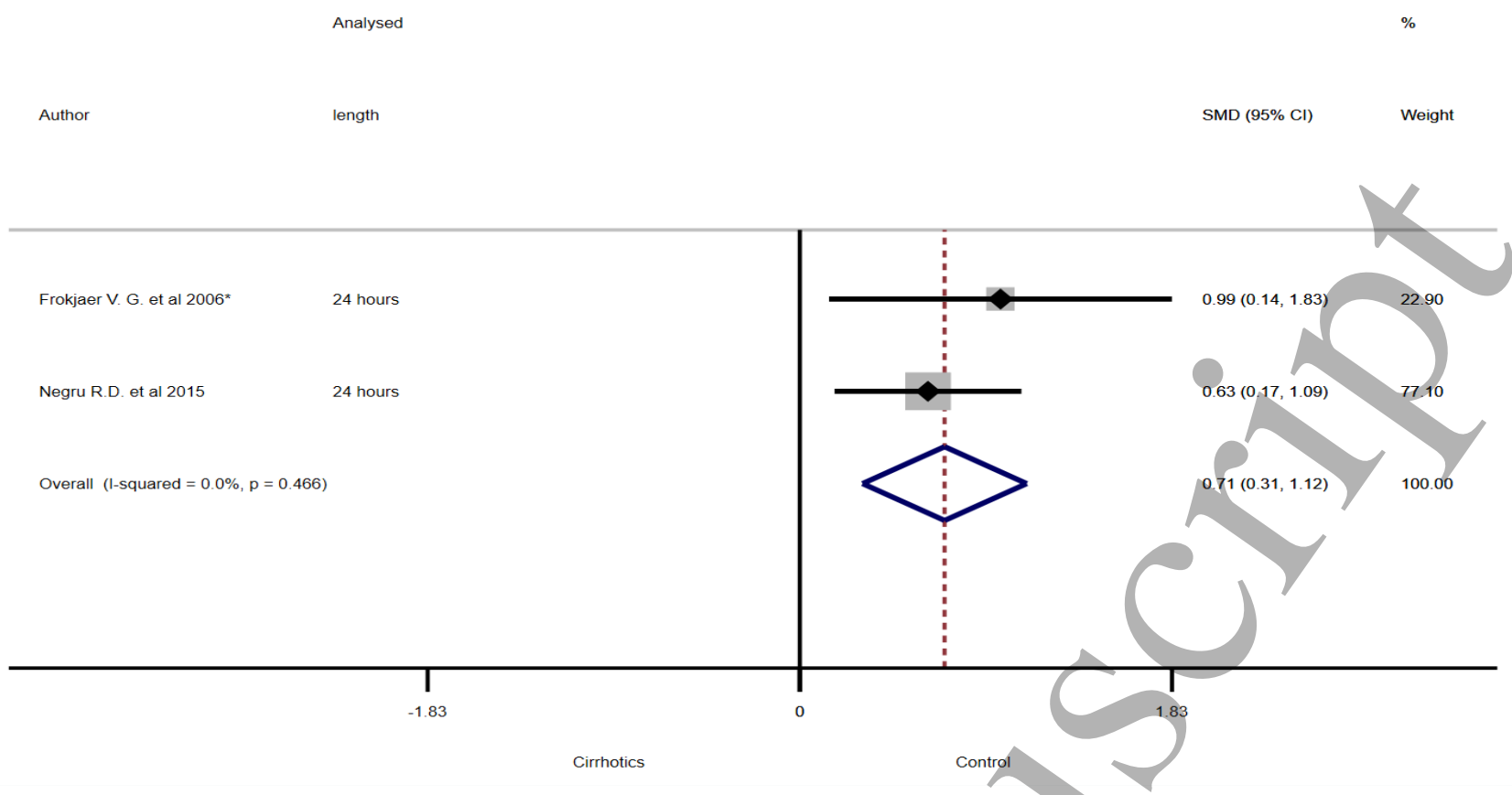

Figure 3d

Figure $\mathbf{3}$ (a, b, c, and d). Forest plot for the standardized mean differences (SMD) in HRV frequency domain indices: TP (3a), HF (3b), LF (3c) and VLF (3d) between patients with liver diseases and matched healthy controls. Hedges' $G$ effect size estimates were calculated with $95 \%$ confidence interval and computed using random effect model. The width of the solid black diamonds represents $95 \%$ confidence interval of the effect sizes of each of the pooled studies and the blue diamond and vertical red dotted line indicates the pooled random or fixed effect sizes.

\section{HRV Non-linear Indices}

A total of 2 studies reported significant difference in non-linear HRV indices between patients with cirrhosis and healthy controls $(13,27)$. Four non-linear indices were reported including short-term (SD1) and longterm (SD2) HRV extracted from the Poincare' plot, Sample Entropy and scaling exponent $(\alpha)$ calculated using detrended fluctuation analysis (DFA). Short-term and long-term variability (SD1 and SD2) of Poincare plot as well as Sample Entropy was reported to be significantly reduced in cirrhosis in one study (Table S13) (13). The short-term scaling exponent (DFA $\alpha 1$ ) which indicates the fractal-like pattern of cardiac rhythm was also reported to be altered in cirrhosis compared with healthy controls in one study [6]. 


\section{HRV in Survival Analysis}

An overall of 7 studies assessed whether HRV can predicts survival in patients with cirrhosis for a follow-up period between 3 to 24 months $(13-15,22,38-40)$. All studies concluded that HRV indices were significantly different between survivors and non-survivors. Indeed, based on the hazard or odds ratios reported, increased DFA $\alpha 2$, SD2, CSDNN, SDNN and VLF were significantly correlated with increased survival (Table 3). Of the 7 studies, 4 reported that HRV indices including DFA $\alpha 2$, cSDNN (corrected SDNN), SD2, and SDNN may predict mortality in cirrhosis independent of MELD and/or Child-Pugh scores. 
Table 3. Characteristics of studies that reported the HRV indices as predictors of survival in patients with cirrhosis.

\begin{tabular}{|c|c|c|c|c|c|c|c|c|c|c|}
\hline $\begin{array}{l}\text { Author, } \\
\text { Year }\end{array}$ & Conclusion & $\begin{array}{l}\text { Sample } \\
\text { Size }\end{array}$ & $\begin{array}{l}\text { Follow-up } \\
\text { (Months) }\end{array}$ & $\begin{array}{l}\text { Analysis } \\
\text { time /length }\end{array}$ & $\begin{array}{l}\text { Non- } \\
\text { Survivor (\%) }\end{array}$ & HRV analysed & $\begin{array}{l}\text { HRV of Non-survivors } \\
\text { (Mean } \pm S D)\end{array}$ & $\begin{array}{l}\text { HRV of Survivors (Mean } \\
\pm S D \text { ) }\end{array}$ & Hazard/Odds Ratio $(95 \% \mathrm{Cl})$ of HRV index & $\begin{array}{l}\text { HRV indices that are } \\
\text { predictor of survivor } \\
\text { independently of MELD or } \\
\text { Child-Pugh scores }\end{array}$ \\
\hline $\begin{array}{l}\text { Ates F. et } \\
\text { al. } 2006 \\
\text { (22) }\end{array}$ & $\begin{array}{l}\text { HRV indices also significantly reduced } \\
\text { in non-survivor vs survivors after } 2 \\
\text { years of follow-up. }\end{array}$ & 30 & 24 & 24 hours & $13(43 \%)$ & $\begin{array}{l}\text { mean NN, SDNN, } \\
\text { SDANN, RMSSD, } \\
\text { pNN50 }\end{array}$ & 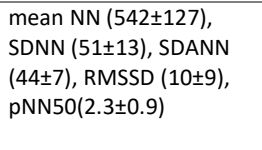 & 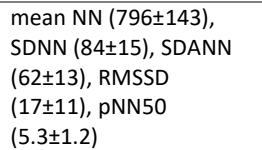 & NR & NR \\
\hline $\begin{array}{l}\text { Bottaro } \\
\text { et al. } \\
2020(15)\end{array}$ & $\begin{array}{l}\text { HRV long term fractal-like exponent } \\
\text { (DFA a1) predicts mortality in cirrhotic } \\
\text { patients independent of MELD and } \\
\text { Child-Pugh score. }\end{array}$ & 38 & 12 & 24 hours & & $\begin{array}{l}\text { SDNN, CSDNN, SD1, } \\
\text { SD2, VLF, LF, HF, } \\
\text { DFA } \alpha 1, \text { DFA } \alpha 2\end{array}$ & 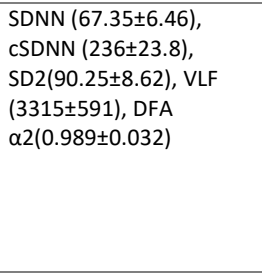 & 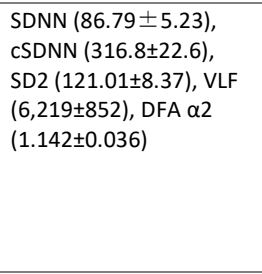 & 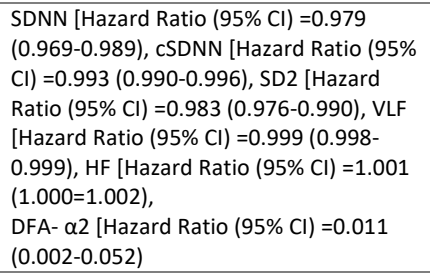 & DFA $\alpha 2$ \\
\hline $\begin{array}{l}\text { Bhogal } \\
\text { A.S. et al. } \\
2019 \text { (39) }\end{array}$ & $\begin{array}{l}\text { HRV indices (SD2 and CSDNN) } \\
\text { predicted survival in cirrhotic patients } \\
\text { independent of MELD and Child-Pugh } \\
\text { scores. }\end{array}$ & 74 & 18 & $8 \mathrm{~min}$ & $24(32 \%)$ & $\begin{array}{l}\text { mean HR, SDNN, } \\
\text { CSDNN, SD1, SD2, } \\
\text { VLF, LF, HF, LF/HF, } \\
\text { SampEn, DFA } \alpha 1 \text {, } \\
\text { DFA } \alpha 2, \text { Kurtosis, } \\
\text { Skewness }\end{array}$ & $\begin{array}{l}\text { SDNN (18.9 } \pm 2.0), \mathrm{CSDNN} \\
(68.1 \pm 5.4), \mathrm{SD} 1 \\
(9.5 \pm 1.3), \mathrm{SD} 2 \\
(24.8 \pm 2.5), \mathrm{VLF} \\
(205 \pm 38), \mathrm{LF}(89 \pm 33), \mathrm{HF} \\
(80 \pm 30)\end{array}$ & 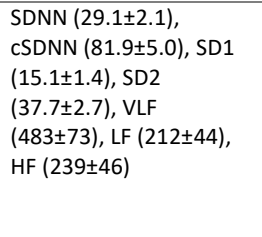 & $\begin{array}{l}\text { SDNN [Hazard Ratio (95\% Cl): } 0.935 \\
\text { (0.895-0.977), cSDNN [Hazard Ratio (95\% } \\
\text { CI): 0.975 (0.959-0.991), SD1 [Hazard } \\
\text { Ratio (95\% CI): 0.919 (o.861-0.980), SD2 } \\
\text { [Hazard Ratio (95\% Cl): } 0.950 \text { (0.918- } \\
\text { 0.982), VLF [Hazard Ratio (95\% Cl): 0.997 } \\
\text { (0.995-0.999), HF [Hazard Ratio (95\% CI): } \\
\text { 0.995 (0.991-0.999) }\end{array}$ & CSDNN, SD2 \\
\hline $\begin{array}{l}\text { Jansen C. } \\
\text { et al. } \\
2019 \text { (38) }\end{array}$ & $\begin{array}{l}\text { Baseline SDNN predicts 90-day } \\
\text { survival in cirrhotic patients } \\
\text { independent of actual indices of } \\
\text { severity. }\end{array}$ & & 3 & $5 \mathrm{~min}$ & $12(11 \%)$ & SDNN & SDNN (11 (10-12)) & $\operatorname{SDNN}(26(17-38))$ & $\begin{array}{l}\text { SDNN [Odds Ratio }(95 \%)=0.79(0.65- \\
0.97)]\end{array}$ & SDNN \\
\hline $\begin{array}{l}\text { Mani A.R. } \\
\text { et al. } \\
2009 \text { (13) }\end{array}$ & $\begin{array}{l}\text { There is } 8 \% \text { increase in the relative } \\
\text { risk of death for every } 1 \mathrm{~ms} \text { drop in } \\
\text { SD2 }\end{array}$ & 80 & 20.3 & $5 \mathrm{~min}$ & $11(14 \%)$ & SD1, SD2 & NR & NR & $\begin{array}{l}\text { SD2 [Hazard Ratio }(95 \% \mathrm{Cl})=0.923 \\
(0.864-0.982)]\end{array}$ & NR \\
\hline $\begin{array}{l}\text { Satti R. et } \\
\text { al. } 2019 \\
\text { (14) }\end{array}$ & $\begin{array}{l}\text { While SD1 and SD2 significantly } \\
\text { predicted survival, only SD2 predicted } \\
\text { survival of cirrhotic patients } \\
\text { independently of MELD }\end{array}$ & 74 & 18 & $8 \mathrm{~min}$ & $24(32 \%)$ & $\begin{array}{l}\text { SD1 (lagged), SD2 } \\
\text { (lagged) and } \\
\text { Pearson's } r\end{array}$ & NR & NR & $\begin{array}{l}\text { SD2 [Hazard Ratio }(95 \% \mathrm{Cl})=0.950 \\
(0.918-0.982)]\end{array}$ & SD2 \\
\hline
\end{tabular}

HRV, Heart rate Variability; NN Interval, time lapse between consecutive QRS complexes of ECG recording; SDNN, Standard deviation of NN intervals; cSDNN, corrected SDNN; ms, millisecond; SDANN, Standard deviation of the average NN intervals for each 5-minute segments deduced from a 24-hour ECG recoding; pNN50, Percentage of successive RR intervals that vary by more than 50ms; RMSSD, Root mean square of differences in successive NN interval; TINN, Triangular Interpolation of the NN intervals' histogram; TP, Total Power; VLF Very Low Frequency; LF, Low Frequency; HF, High Frequency; LF/HF, Ratio of LF to HF; SD1, Poincare plot Standard Deviation perpendicular to the line of identity; SD2, Poincare plot Standard Deviation along the line of identity; ApEn, Approximate Entropy; SampEn, Sample Entropy; DFA $\alpha 1$, Short-term fluctuation of Detrended Fluctuation Analysis; DFA a2, Long-term fluctuation of Detrended Fluctuation Analysis; DC, Deceleration Capacity; MELD, Model for End-stage Liver Disease; Cl, Confidence Interval; SD, Standard Deviation; NR, Not Reported. 


\section{Discussion}

We report here the effect of cirrhosis on autonomic cardiac regulation measured by indices of heart rate variability. Significant difference in HRV was observed between patients with cirrhosis and healthy controls, albeit between-studies heterogeneities were high. To address the heterogeneity of included studies, we used mostly random-effect model and pooled the standardized mean difference (SMD). In most cases, the HRV indices indicated autonomic dysfunction as shown previously (41). Some HRV indices (DFA $\alpha 2$, SD2, CSDNN and SDNN) also exhibited a significant correlation with severity of cirrhosis and survival of patients. Precisely, there was significant reduction in HRV time and frequency domain indices including SDNN, SDNN index, SDANN, RMSSD, pNN50 as well as TP, HF, LF and VLF in cirrhosis which correlated with disease severity. The relationship between cirrhosis and the ratio of LF: HF, which traditionally represent sympathovagal cardiac regulation is not clear with one study reporting increased (31) and two studies reporting decrease in cirrhosis $(26,30)$.

Importantly, the mini-systematic review shows that some indices of HRV predict survival in cirrhosis independently of measures of severity (MELD score). This is consistent with a recent report whereby SDNN was shown to independently predict mortality in patients with decompensated cirrhosis. Further, Jansen et al. also showed that SDNN was significantly reduced and correlated with increased plasma level of inflammatory biomarkers and severity of cirrhosis (38). Indeed, the association between cardiac autonomic dysregulation and systemic inflammation has been reported in cirrhosis (13) as well as in other diseases (42, 43). Similarly, the development of acute on chronic liver failure (ACLF) has been extensively linked with systemic inflammation (44-46). Thus, the suggestion that sudden reduction in HRV can be used to detect dynamic changes indicative of early acute decompensation in patients with cirrhosis (38). However, knowledge on the mechanism of cardiac autonomic dysfunction during systemic inflammation have only be reported in animal models and awaits further investigation in humans (47-50). Also, data are emerging to show that HRV correlates with sub-clinical hepatic encephalopathy (13), and may therefore become an indirect means to identify patients most likley to have sub-clinical hepatic encephalopathy without the need for an EEG (51). Perhaps, HRV may provide a relatively simpler and portable yet effective assessment of covert hepatic encephalopathy.

Reduction in HRV is not unique to cirrhosis and have been reported in non-cirrhotic liver patients. For example, Keresztes et al. reported significant reduction in HRV time and frequency domains in patients with primary biliary cholangitis compared with age-matched healthy controls. Indeed, $58 \%$ of the PBC patients studied also had autonomic dysfunction with abnormal cardiovascular reflex tests (52). Further, patients with chronic hepatitis $\mathrm{C}$ infection have impaired autonomic function assessed by HRV time and frequency indices, and this correlates with the degree of liver injury as assessed by serum alanine aminotransferase levels (53). 
This study also observed that non-linear HRV indices were significantly impaired in cirrhosis. Short and long term HRV, measured by SD1 and SD2 respectively and sample entropy were reduced in cirrhosis compared with healthy controls. Our findings substantiate the report by Bhogal et al. in which SD2 as well as CSDNN were found to predict mortality independent of MELD in patients with cirrhosis (39). The long-term fractallike scaling exponent (DFA $\alpha 2$ ) was also lower in patients with cirrhosis predicts mortality independent of the measures of severity of liver failure (13). Non-linear HRV indices are measures of unpredictability and provides an index of complexity in inter-beats intervals. Increased complexity may be interpreted physiologically as increased flexibility and inclination of the cardiac rhythm to respond to environmental changes and autonomic nervous control. Indeed, increased memory length of cardiac rhythm, which can be interpreted as reduced physiological controllability, has been reported in patients with liver cirrhosis compared to healthy controls (54). Likewise, we recently showed that heart rate turbulence onset (TO) following premature ventricular contraction, a phenomenon that is linked with autonomic nervous control is reduced and predicts survival in cirrhosis (55). Put together, while the mechanistic link remain unclear, autonomic regulation of the cardiac rhythm is dysregulated in cirrhosis and may improve clinical diagnosis and prognosis of patients. Finally, while lower HRV complexity (Sample Entropy) have been reported in cirrhosis, its association with poor outcome has not been reported and should be a focus of future investigation.

Further, while HRV have been shown to be a potential candidate for clinical diagnosis and prognosis, it is important to be aware of dependency of HRV measures on experimental conditions such as patients' position (supine, seated etc.), time of the day (circadian rhythm) and how active the patient is. These factors have significant effect on baroreflex and autonomic regulation of heart rhythm. This is particularly important in cirrhosis as baroreflex sensitivity is impaired and the patients have altered vascular compliance (56). Thus, if HRV is going be utilised in clinical management of patients with cirrhosis, these various factors should be standardised. It is also well known that respiratory rhythm has significant influence on HRV (particularly on short-term HRV indices) since cirrhosis is associated with respiratory complications such as hepatopulmonary syndrome $(57,58)$. It is essential to also consider the influences of respiratory rhythm on heart rate dynamics in patients with cirrhosis in future investigations.

This study has several limitations. Because of the difference in the time of ECG recording in the studies, it was not possible to assess the role of circadian rhythm in HRV. Further, few studies reported non-linear indices of HRV, and thus data could not be pooled to assess the differences or the survival analysis because of the variability in the follow-up time. Finally, as only $5 \%$ of the generated studies were included, the result of this systematic review may be skewed by study location, selection and publication biases. 
We conclude that HRV analysis has the potential to be applied in both clinical and research settings for the evaluation of autonomic dysfunction in patients with cirrhosis and may be of value in the early detection of subclinical deterioration such as early covert hepatic encephalopathy or acute on chronic liver decompensation. Further, HRV is an independent predictor of outcome of cirrhosis and may improve the predictive power of MELD and Child-Pugh. Finally, despite the potential, variation in techniques of HRV measurement remain the main barrier to useful interpretation and applicability. Indeed, to generate robust data, there needs to be standardisation of techniques including ECG recording and HRV measurement in future. We hope that this paper provides an impetus to agreed standardisation of methodology to enable this field to develop. 


\section{Reference}

1. Leon DA, McCambridge J. Liver cirrhosis mortality rates in Britain from 1950 to 2002: an analysis of routine data. Lancet (London, England). 2006;367(9504):52-56.

2. Parra A, Juanes A, Losada CP, Alvarez-Sesmero S, Santana VD, Marti I, Urricelqui J, Rentero D. Psychotic symptoms in COVID-19 patients. A retrospective descriptive study. Psychiatry Research. 2020;291 (no pagination).

3. Schuppan D, Afdhal NH. Liver cirrhosis. Lancet (London, England). 2008;371(9615):838-851.

4. D'Amico G, Garcia-Tsao G, Pagliaro L. Natural history and prognostic indicators of survival in cirrhosis: a systematic review of 118 studies. Journal of hepatology. 2006;44(1):217-231.

5. Kumar R, Mehta G, Jalan R. Acute-on-chronic liver failure. Clinical medicine (London, England). 2020;20(5):501-504.

6. Barber KM, Pioli SE, Blackwell JE, Collett D, Neuberger JM, Gimson AE. Development of a UK score for patients with end-stage liver disease. In. Hepatology: JOHN WILEY \& SONS INC 111/RIVER ST, HOBOKEN, NJ 07030 USA; 2007. p. 510A-510A.

7. Rajendra Acharya U, Paul Joseph K, Kannathal N, Lim CM, Suri JS. Heart rate variability: a review. Medical \& biological engineering \& computing. 2006;44(12):1031-1051.

8. Tsuji H, Venditti FJ, Manders ES, Evans JC, Larson MG, Feldman CL, Levy D. Reduced heart rate variability and mortality risk in an elderly cohort. The Framingham Heart Study. Circulation. 1994;90(2):878-883.

9. Vanderlei LC, Pastre CM, Hoshi RA, Carvalho TD, Godoy MF. Basic notions of heart rate variability and its clinical applicability. Revista brasileira de cirurgia cardiovascular : orgao oficial da Sociedade Brasileira de Cirurgia Cardiovascular. 2009;24(2):205-217.

10. Bhogal AS, Montagnese S, Mani AR. The consideration of heart rate complexity as a co-morbidity factor for liver transplantation selection procedures. Liver International. 2018;38(2):380-380.

11. Fouad YM, Yehia R. Hepato-cardiac disorders. World journal of hepatology. 2014;6(1):41-54.

12. Ferenci P. Hepatic encephalopathy. Gastroenterology report. 2017;5(2):138-147.

13. Mani AR, Montagnese S, Jackson CD, Jenkins CW, Head IM, Stephens RC, Moore KP, Morgan MY. Decreased heart rate variability in patients with cirrhosis relates to the presence and degree of hepatic encephalopathy. Am J Physiol Gastrointest Liver Physiol. 2009;296(2):G330-338.

14. Satti R, Abid NUH, Bottaro M, De Rui M, Garrido M, Rauofy MR, Montagnese S, Mani AR. The application of the extended Poincare plot in the analysis of physiological variabilities. Frontiers in Physiology.

2019;10(FEB):116.

15. Bottaro M, Abid N-U-H, El-Azizi I, Hallett J, Koranteng A, Formentin C, Montagnese S, Mani AR. Skin temperature variability is an independent predictor of survival in patients with cirrhosis. Physiological Reports. 2020;8(12):e14452.

16. Moher D, Shamseer L, Clarke M, Ghersi D, Liberati A, Petticrew M, Shekelle P, Stewart LA, Group P-P. Preferred reporting items for systematic review and meta-analysis protocols (PRISMA-P) 2015 statement. Systematic Reviews. 2015;4(1):1.

17. Luo D, Wan X, Liu J, Tong T. Optimally estimating the sample mean from the sample size, median, mid-range, and/or mid-quartile range. Stat Methods Med Res. 2018;27(6):1785-1805.

18. Shi J, Luo D, Weng H, Zeng X-T, Lin L, Chu H, Tong T. Optimally estimating the sample standard deviation from the five-number summary. Research Synthesis Methods;n/a(n/a).

19. Borenstein M, Hedges LV, Higgins JP, Rothstein HR. Introduction to meta-analysis: John Wiley \& Sons; 2011.

20. Higgins JPT, Thompson SG, Deeks JJ, Altman DG. Measuring inconsistency in meta-analyses. BMJ. 2003;327(7414):557-560.

21. Hopkins WG, Marshall SW, Batterham AM, Hanin J. Progressive statistics for studies in sports medicine and exercise science. Medicine and science in sports and exercise. 2009;41(1):3-13.

22. Ates F, Topal E, Kosar F, Karincaoglu M, Yildirim B, Aksoy Y, Aladag M, Harputluoglu MM, Demirel U, Alan H, Hilmioglu F. The relationship of heart rate variability with severity and prognosis of cirrhosis. Dig Dis Sci. 2006;51(9):1614-1618.

23. Baratta L, Tubani L, Merli M, Labbadia F, Facchini D, De Marco R, Rossi M, Attili AF, Berloco P, Ginanni Corradini S. Long-term effect of liver transplantation on cirrhotic autonomic cardiac dysfunction. Dig Liver Dis. 2010;42(2):131-136.

24. Coelho L, Saraiva S, Guimaraes H, Freitas D, Providencia LA. Autonomic function in chronic liver disease assessed by Heart Rate Variability Study. Rev Port Cardiol. 2001;20(1):25-36.

25. Frokjaer VG, Strauss GI, Mehlsen J, Knudsen GM, Rasmussen V, Larsen FS. Autonomic dysfunction and impaired cerebral autoregulation in cirrhosis. Clin Auton Res. 2006;16(3):208-216. 
26. Iga A, Nomura M, Sawada $\mathrm{Y}$, Ito $\mathrm{S}$, Nakaya Y. Autonomic nervous dysfunction in patients with liver cirrhosis using 123I-metaiodobenzylguanidine myocardial scintigraphy and spectrum analysis of heart-rate variability. J Gastroenterol Hepatol. 2003;18(6):651-659.

27. Ko FY, Yang AC, Tsai SJ, Zhou Y, Xu LM. Physiologic and laboratory correlates of depression, anxiety, and poor sleep in liver cirrhosis. BMC Gastroenterol. 2013;13:18.

28. Lazzeri C, La Villa G, Laffi G, Vecchiarino S, Gambilonghi F, Gentilini P, Franchi F. Autonomic regulation of heart rate and QT interval in nonalcoholic cirrhosis with ascites. Digestion. 1997;58(6):580-586

29. Milovanovic B, Milinic N, Trifunovic D, Krotin M, Filipovic B, Bisenic V, Djuric D. Autonomic dysfunction in alcoholic cirrhosis and its relation to sudden cardiac death risk predictors. Gen Physiol Biophys. 2009;28 Spec No:251-261.

30. Miyajima H, Nomura M, Muguruma N, Okahisa T, Shibata H, Okamura S, Honda H, Shimizu I, Harada M, Saito $\mathrm{K}$, Nakaya $\mathrm{Y}$, Ito $\mathrm{S}$. Relationship among gastric motility, autonomic activity, and portal hemodynamics in patients with liver cirrhosis. J Gastroenterol Hepatol. 2001;16(6):647-659.

31. Moller S, Mortensen C, Bendtsen F, Jensen LT, Gotze JP, Madsen JL. Cardiac sympathetic imaging with mIBG in cirrhosis and portal hypertension: relation to autonomic and cardiac function. Am J Physiol Gastrointest Liver Physiol. 2012;303(11):G1228-1235.

32. Nagasako CK, de Oliveira Figueiredo MJ, de Souza Almeida JR, Lorena SL, Akasaka HM, Pavan CR, Yamanaka A, Pereira TS, Soares EC, Mesquita MA. Investigation of autonomic function and orocecal transit time in patients with nonalcoholic cirrhosis and the potential influence of these factors on disease outcome. J Clin Gastroenterol. 2009;43(9):884-889.

33. Negru RD, Cojocaru DC, Mitu F, Aursulesei V, Trifan A. Contribution of the heart rate variability parameters in evaluation of liver cirrhosis severity and associated autonomic dysfunction. Acta Medica Mediterranea. 2015;31(5):1087-1092.

34. Shaffer F, McCraty R, Zerr CL. A healthy heart is not a metronome: an integrative review of the heart's anatomy and heart rate variability. Frontiers in psychology. 2014;5:1040.

35. Shaffer F, Ginsberg JP. An Overview of Heart Rate Variability Metrics and Norms. Frontiers in public health. 2017;5:258.

36. Deeks J, Higgins J, Altman D. 9.2. 3.2 The standardized mean difference. Higgins JPG, Green S Cochrane Handbook for Systematic Reviews of Interventions. 2011;5(0).

37. Billman GE. The LF/HF ratio does not accurately measure cardiac sympatho-vagal balance. Front Physiol. 2013;4:26.

38. Jansen C, Chatterjee DA, Thomsen KL, Al-Kassou B, Sawhney R, Jones H, Gallego-Leon A, Lehmann J, Pohlmann A, Nickenig G, Strassburg CP, Andrié R, Jalan R, Linhart M, Trebicka J, Mookerjee RP. Significant reduction in heart rate variability is a feature of acute decompensation of cirrhosis and predicts 90-day mortality. Alimentary Pharmacology \& Therapeutics. 2019;50(5):568-579.

39. Bhogal AS, De Rui M, Pavanello D, El-Azizi I, Rowshan S, Amodio P, Montagnese S, Mani AR. Which heart rate variability index is an independent predictor of mortality in cirrhosis? Dig Liver Dis. 2019;51(5):695-702.

40. Chan K-C, Yeh J-R, Sun W-Z. The role of autonomic dysfunction in predicting 1-year mortality after liver transplantation. Liver International. 2017;37(8):1239-1248.

41. Amaral J, Salatini R, Arab C, Abreu LC, Valenti VE, Monteiro CBM, Tannuri U, Tannuri ACA. Non-Alcoholic Cirrhosis and Heart Rate Variability: A Systematic Mini-Review. Medicina (Kaunas, Lithuania). 2020;56(3).

42. Lanza GA, Pitocco D, Navarese EP, Sestito A, Sgueglia GA, Manto A, Infusino F, Musella T, Ghirlanda G, Crea F. Association between cardiac autonomic dysfunction and inflammation in type 1 diabetic patients: effect of beta-blockade. European heart journal. 2007;28(7):814-820.

43. Lanza GA, Sgueglia GA, Cianflone D, Rebuzzi AG, Angeloni G, Sestito A, Infusino F, Crea F, Maseri A. Relation of heart rate variability to serum levels of $C$-reactive protein in patients with unstable angina pectoris. The American journal of cardiology. 2006;97(12):1702-1706.

44. Clària J, Arroyo V, Moreau R. The Acute-on-Chronic Liver Failure Syndrome, or When the Innate Immune System Goes Astray. Journal of immunology (Baltimore, Md : 1950). 2016;197(10):3755-3761.

45. Mücke MM, Rumyantseva T, Mücke VT, Schwarzkopf K, Joshi S, Kempf VAJ, Welsch C, Zeuzem S, Lange CM. Bacterial infection-triggered acute-on-chronic liver failure is associated with increased mortality. Liver international : official journal of the International Association for the Study of the Liver. 2018;38(4):645-653.

46. Lange CM. Systemic inflammation in hepatorenal syndrome - A target for novel treatment strategies? Liver international : official journal of the International Association for the Study of the Liver. 2019;39(7):11991201.

47. Eftekhari G, Shojaei A, Raoufy MR, Azizi H, Semnanian S, Mani AR. Neonatal Sepsis Alters the Excitability of Regular Spiking Cells in the Nucleus of the Solitary Tract in Rats. Shock (Augusta, Ga). 2020;54(2):265-271. 
48. Gholami M, Mazaheri P, Mohamadi A, Dehpour T, Safari F, Hajizadeh S, Moore KP, Mani AR. Endotoxemia is associated with partial uncoupling of cardiac pacemaker from cholinergic neural control in rats. Shock (Augusta, Ga). 2012;37(2):219-227.

49. Hajiasgharzadeh K, Mirnajafi-Zadeh J, Mani AR. Interleukin-6 impairs chronotropic responsiveness to cholinergic stimulation and decreases heart rate variability in mice. European journal of pharmacology. 2011;673(1-3):70-77.

50. Haddadian Z, Eftekhari G, Mazloom R, Jazaeri F, Dehpour AR, Mani AR. Effect of endotoxin on heart rate dynamics in rats with cirrhosis. Autonomic neuroscience : basic \& clinical. 2013;177(2):104-113.

51. Nabi E, Bajaj JS. Useful tests for hepatic encephalopathy in clinical practice. Current gastroenterology reports. 2014;16(1):362.

52. Keresztes K, Istenes I, Folhoffer A, Lakatos PL, Horvath A, Csak T, Varga P, Kempler P, Szalay F. Autonomic and sensory nerve dysfunction in primary biliary cirrhosis. World J Gastroenterol. 2004;10(20):3039-3043.

53. Osztovits J, Horvath T, Abonyi M, Toth T, Visnyei Z, Beko G, Csak T, Lakatos PL, Littvay L, Feher J, Kempler P, Kollai M, Szalay F. Chronic hepatitis $C$ virus infection associated with autonomic dysfunction. Liver international : official journal of the International Association for the Study of the Liver. 2009;29(10):14731478.

54. Shirazi AH, Raoufy MR, Ebadi H, De Rui M, Schiff S, Mazloom R, Hajizadeh S, Gharibzadeh S, Dehpour AR, Amodio P. Quantifying memory in complex physiological time-series. PLoS One. 2013;8(9):e72854.

55. Oyelade T, Canciani G, Bottaro M, Zaccaria M, Formentin C, Moore K, Montagnese S, Mani AR. Heart Rate Turbulence Predicts Survival Independently From Severity of Liver Dysfunction in Patients With Cirrhosis. Front Physiol. 2020;11:602456.

56. Møller S, Iversen JS, Henriksen JH, Bendtsen F. Reduced baroreflex sensitivity in alcoholic cirrhosis: relations to hemodynamics and humoral systems. American Journal of Physiology-Heart and Circulatory Physiology. 2007;292(6):H2966-H2972.

57. Grilo-Bensusan I, Pascasio-Acevedo JM. Hepatopulmonary syndrome: What we know and what we would like to know. World J Gastroenterol. 2016;22(25):5728-5741.

58. Wessel N, Riedl M, Kurths J. Is the normal heart rate "chaotic" due to respiration? Chaos (Woodbury, NY). 2009;19(2):028508. 